\title{
Health Risk of the Shallow Groundwater and Its Suitability for Drinking Purpose in Tongchuan, China
}

\author{
Abel Nsabimana ${ }^{1,2} \mathbb{D}^{\text {, Peiyue }} \mathrm{Li}^{1,2,3, * \mathbb{D}}$, Song $\mathrm{He}^{1,2}$, Xiaodong He ${ }^{1,2}$, S. M. Khorshed Alam ${ }^{1,2}$ \\ and Misbah Fida ${ }^{1,2}$ \\ 1 School of Water and Environment, Chang'an University, No. 126 Yanta Road, Xi'an 710054, China; \\ nsabby41@gmail.com (A.N.); hesong_chd@163.com (S.H.); hexiaod3@163.com (X.H.); \\ khorshed11_31@yahoo.com (S.M.K.A.); misbahfida20@gmail.com (M.F.) \\ 2 Key Laboratory of Subsurface Hydrology and Ecological Effects in Arid Region of the Ministry of Education, \\ Chang'an University, No. 126 Yanta Road, Xi'an 710054, China \\ 3 School of Water Resources and Environment, Hebei GEO University, No. 136 East Huai'an Road, \\ Shijiazhuang 050031, China \\ * Correspondence: lipy2@163.com or peiyueli@chd.edu.cn
}

Citation: Nsabimana, A.; Li, P.;

He, S.; He, X.; Alam, S.M.K.; Fida, M. Health Risk of the Shallow

Groundwater and Its Suitability for Drinking Purpose in Tongchuan, China. Water 2021, 13, 3256. https:// doi.org/10.3390/w13223256

Academic Editor:

Dimitrios E. Alexakis

Received: 16 October 2021

Accepted: 15 November 2021

Published: 17 November 2021

Publisher's Note: MDPI stays neutral with regard to jurisdictional claims in published maps and institutional affiliations.

Copyright: (c) 2021 by the authors. Licensee MDPI, Basel, Switzerland. This article is an open access article distributed under the terms and conditions of the Creative Commons Attribution (CC BY) license (https:/ / creativecommons.org/licenses/by/ $4.0 /)$.

\begin{abstract}
Studying the quality and health risks of groundwater is of great significance for sustainable water resources utilization, especially in arid and semi-arid areas around the world. The current study is carried out to evaluate the quality and potential health risks of groundwater in the Tongchuan area on the Loess Plateau, northwest China. Water quality index (WQI) and hydrochemical correlation analysis were implemented to understand the status of groundwater quality. Daily average exposure dosages through the oral and dermal contact exposure pathways were taken into consideration to calculate the health risks to the human body. Additionally, graphical approaches such as Piper diagram, Durov diagram and GIS mapping were used to help better understand the results of this study. The WQI approach showed that $77.1 \%$ of the samples were of excellent quality. The most significant parameters affecting water quality were $\mathrm{NO}_{3}{ }^{-}, \mathrm{F}^{-}$, and $\mathrm{Cr}^{6+}$. The health risk assessment results showed that $27.1 \%$ and $54.2 \%$ of the samples lead to non-carcinogenic risks through oral intake for adults and children, respectively. In contrast, $12.5 \%$ of the groundwater samples would result in carcinogenic risks to the residents. This study showed that the WQI method needs to be supplemented by a health risk evaluation to obtain comprehensive results for groundwater quality protection and management in the Tongchuan area.
\end{abstract}

Keywords: water quality index; health risk assessment; Tongchuan city; Loess Plateau

\section{Introduction}

Groundwater is an important source for drinking and other various purposes for the majority of the population around the world, especially in arid and semiarid regions where precipitation and runoff are rare [1-6]. In addition to drinking, groundwater is useful for domestic, industrial and agricultural purposes. Due to the increased demand for groundwater, the groundwater table is subject to fluctuations, and aquifers are becoming contaminated in the context of climate change, rapid population growth, industrial development and urban expansions [7-12]. This situation is also aggravated where natural phenomena are controlling the physicochemical parameters of groundwater, such as rock influences, volcanic eruption or marine salt intrusions [13].

There is a critical increase in freshwater demand correlated with the rapid growth of the population all over the world [14] and intensive agriculture activities [15,16]. The increment of the population also leads to the expansion of cities and municipal waste that affect the groundwater quality through organic and inorganic contaminants [17-20]. Furthermore, industrialization is one of the most significant factors affecting groundwater quality through the effluents released into the nature [21-24]. Papazotos et al. [25] 
investigated the impact of water-rock and agricultural activities in the Psachna Basin (Greece) on groundwater quality and found that groundwater was strongly affected by the ultramafic geological environment with anthropogenic activities as revealed by high concentrations of $\mathrm{Cr}, \mathrm{Cr}^{6+}$, and $\mathrm{NO}_{3}{ }^{-}$. Water-ultramafic rock processes can also increase the concentration of $\mathrm{Cr}$ in groundwater as investigated by Vasileiou et al. [26] in their study on hydrogeochemical processes and natural background levels of chromium in an ultramafic environment in Macedonia (Greece), and they found a high concentration of $\mathrm{Cr}^{6+}$ ranging from 0.5 to $131 \mu \mathrm{g} / \mathrm{L}$ in groundwater of western Vermino Mountain. In addition, Chen et al. [27] found rock dissolution and precipitation of $\mathrm{Ca}-\mathrm{As}$ and $\mathrm{CaF}_{2}$, which controlled a high concentration of As and $\mathrm{CaF}_{2}$ in northwest China. In terms of groundwater pollution by marine intrusion, Zissimos et al. [28] tested the occurrence and distribution of $\mathrm{Cr}$ in groundwater and surface water in Cyprus and found that the highest $\mathrm{Cr}^{6+}$ concentration observed in the Troodos area was $26 \mu \mathrm{g} / \mathrm{L}$. However, the abnormal concentrations of $\mathrm{Cr}^{6+}$ $(460 \mu \mathrm{g} / \mathrm{L})$ and As $(15 \mu \mathrm{g} / \mathrm{L})$ were detected in groundwater along the coastline in the Schinos area (Greece) due to seawater intrusion [29].

Given the importance of groundwater for humanity and considering its vulnerability facing pollution issues as aforementioned, numerous studies have been conducted to evaluate groundwater quality to ensure the health of consumers. As a result, governments and states implemented controlling structures for water quality in order to preserve the population health [14]. In this regard, many groundwater quality investigations have been conducted based on the guidelines set by governments and organizations such as the World Health Organization (WHO) and the Ministry of Environmental Protection of the P.R. China [30]. Based on the aforementioned guidelines, serious drinking groundwater contamination was reported by many scholars all over the world $[15,16,18,31-36]$. However, few of them were associated with groundwater pollution and health risk assessment. To obtain the results, many approaches were used by the researchers. Ni et al. [37] used the geostatistical spatial analysis function of ArcGIS to map the evaluated carcinogenic and non-carcinogenic risks in the Sichuan Basin, China. Their study showed that total cancerous and non-cancerous risks were found in $5 \%$ and $8 \%$ of samples, respectively. Using a comprehensive water quality index assessment, Wu and Sun [38] found that $60 \%$ of sampled water was unsuitable for drinking in the alluvial plain located in mid-west China. Chen and her colleagues [27] used a triangular fuzzy numbers approach to assess health risk by $\mathrm{As}$ and $\mathrm{CaF}_{2}$ in groundwater and found that their concentrations were higher in the shallow groundwater, which exceeded the acceptable limit $\left(1 \times 10^{-6}\right)$ set by the Ministry of Environmental Protection of the P.R. China for $\mathrm{Cr}^{6+}$ and As [30].

Studies performed in the northwest of China reported high nitrate concentrations representing health risk concerns for the population [38] due to anthropogenic activities, especially fertilizers used in agriculture [39]. N-bearing and P-bearing fertilizers can cause the oxidation of geogenic $\mathrm{Cr}$, which results in elevated $\mathrm{Cr}^{6+}$ [19]. Wei et al. [34] also reported that nitrate pollution was a major environmental geological problem in the groundwater in part of China. In addition, Li et al. [21] reported a severe water stress in the Chinese Loess Plateau aggravated by the high fluoride concentration in drinking water.

The Tongchuan region is situated in the middle edges of the Loess Plateau and is adjacent to the Weihe River Valley and Guanzhong Basin, and the main water supply aquifer in this area is a phreatic aquifer with thickness ranging from 25 to $60 \mathrm{~m}[34,39]$. The main objective of the present study is to enhance the understanding of the association between water quality and health risk assessment. Specifically, this study aims to characterize the major pollutants in shallow groundwater, to check their concentration based on the depth of wells, to determine the water quality index and make its distribution map, and to assess the water's potential risks to human health. To understand the status of groundwater quality, the water quality index (WQI), hydrochemical correlation analysis, and graphical approaches were used. The health risk assessment was performed considering daily average exposure dosage through oral pathway per unit weight $(\mathrm{mg} /(\mathrm{kg} . \mathrm{d}))$ for drinking water intake; and for dermal contact, the exposure dosage of every single event in $\mathrm{mg} / \mathrm{cm}^{2}$ and 
the skin surface $\left(\mathrm{cm}^{2}\right)$ were taken into consideration. Geographical information system approaches helped to better understand the results of this study.

\section{Materials and Methods}

\subsection{Study Area}

Tongchuan City is $70 \mathrm{~km}$ away from Xi'an City, the capital city of Shaanxi Province (Figure 1). It belongs to the Chinese Loess Plateau, with longitude between $108^{\circ} 35^{\prime} 44^{\prime \prime} \mathrm{E}$ and $109^{\circ} 29^{\prime} 22^{\prime \prime} \mathrm{E}$ and latitude between $34^{\circ} 48^{\prime} 27^{\prime \prime} \mathrm{N}$ and $35^{\circ} 35^{\prime} 23^{\prime \prime} \mathrm{N}$. The altitude of Tongchuan City ranges from 900 to $1350 \mathrm{~m}$ above mean sea level [39]. The study area is situated in the middle edges of Loess Plateau and adjacent to the Weihe River Valley and Guanzhong Basin $[34,40]$. Tongchuan lies in the transition zone of semi-humid and semi-arid climate with annual mean rainfall and evaporation of around 540 and $1964 \mathrm{~mm}$, respectively. The annual temperature of Tongchuan City is $8.9-12{ }^{\circ} \mathrm{C}$ [34,39]. Precipitation, reservoir leakage and irrigation are the main recharges of groundwater, whereas discharge to some rivers such as the Beiluo River and Juhe River, evaporation and artificial extraction [34] are the main discharge pathways of groundwater. Li et al. [39] estimated the groundwater recharge at $52.8 \%$ from precipitation and $40.1 \%$ from irrigation infiltration, whereas $37.4 \%$ and $44.9 \%$ of groundwater were discharged by artificial extraction and the lateral outflow, respectively. Geologically, the study area is dominated by Quaternary loess divided into three landforms, including loess tableland, loess gully and alluvial terrace. Furthermore, this area has several layers from top down [39]: Holocene loess layer and upper Pleistocene loess layer, which are unsaturated. The middle Pleistocene layer is composed of silty clay, which separates the phreatic aquifer and the confined aquifer partially formed by the lower Pleistocene loess layer, alluvial, sand and gravel layers. The phreatic aquifer with a thickness of 25 to $60 \mathrm{~m}$ is the main water supply aquifer in this area.

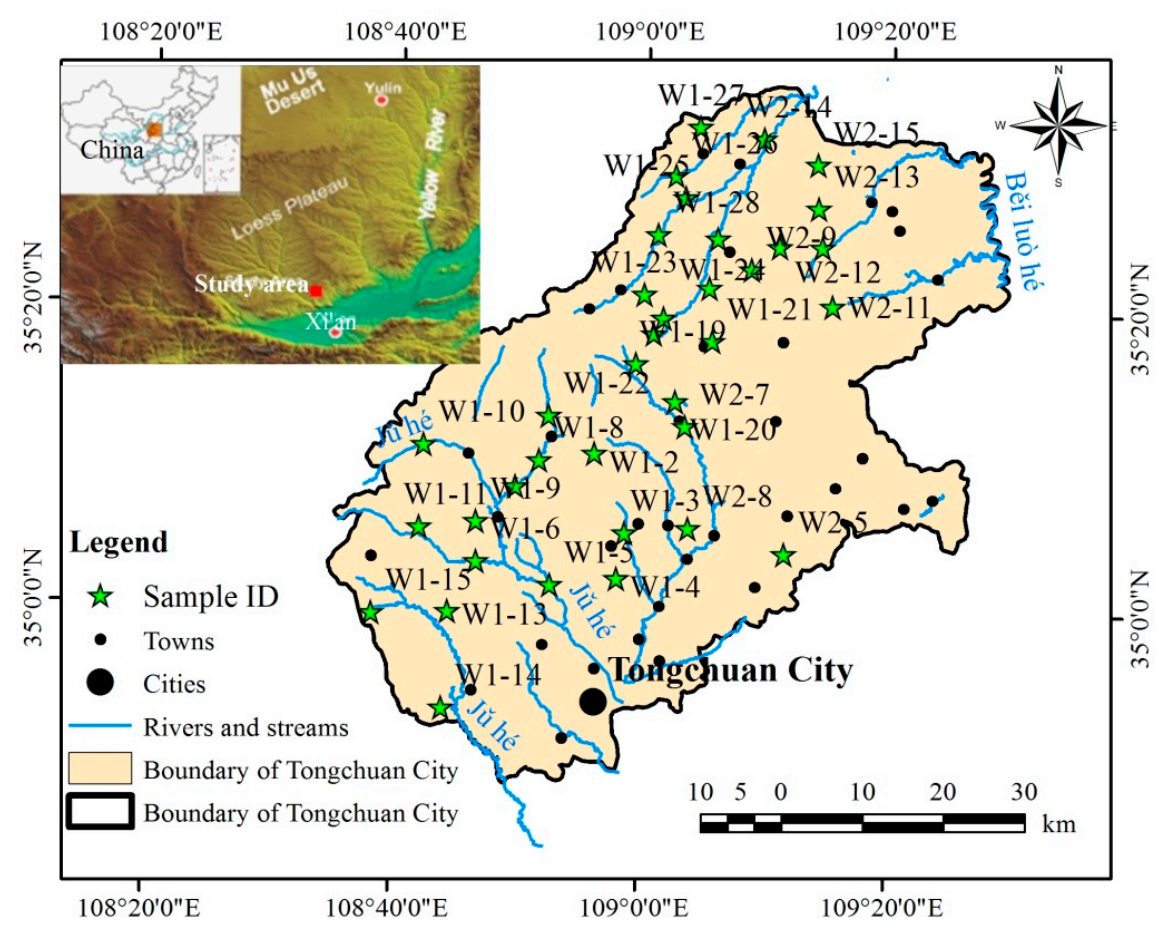

Figure 1. Study area and samples distribution.

\subsection{Groundwater Samples}

For this study, 48 groundwater samples were collected from the wells and boreholes distributed in the study area. The criteria for the selection of water samples were based on the depth of wells, water purposes and the zone of collection. The sampling locations were recorded by coordinates using a portable GPS device and are shown as Figure 1. Samples 
were collected in pre-cleaned plastic polyethylene bottles for physicochemical analysis after the wells were pumped for $10 \mathrm{~min}$. Before sampling, all the containers were washed and rinsed thoroughly with the groundwater to be sampled. Water was filtered through $0.45 \mu \mathrm{m}$ filter during sampling. Sample collection, handling, and preservation complied with the standard procedures recommended by Standard Examination Methods for Drinking Water [30] to ensure data quality and consistency. The water samples were analyzed in the Soil and Water Testing Center of Shaanxi Institute of Engineering Investigation, China.

\subsection{Chemical Analysis and Data Processing}

The samples were analyzed for physical and chemical parameters, including temperature, $\mathrm{pH}$, electrical conductivity (EC), total hardness (TH), total dissolved solids (TDS), major ions $\left(\mathrm{Na}^{+}, \mathrm{K}^{+}, \mathrm{Ca}^{2+}, \mathrm{Mg}^{2+}, \mathrm{Cl}^{-}, \mathrm{SO}_{4}{ }^{2-}, \mathrm{HCO}_{3}{ }^{-}, \mathrm{NO}_{3}{ }^{-}, \mathrm{NO}_{2}{ }^{-}\right.$and $\left.\mathrm{F}^{-}\right)$, and $\mathrm{Cr}^{6+}$. Some parameters such as $\mathrm{pH}, \mathrm{EC}$ and temperature were recorded on the field by portable multi-parameter devices. Drying and weighing approach was used to measure TDS. $\mathrm{Na}^{+}$and $\mathrm{K}^{+}$were determined using flame atomic absorption spectrometer and $\mathrm{TH}, \mathrm{Ca}^{2+}$, and $\mathrm{Mg}^{2+}$ were analyzed using EDTA titrimetric methods. Spectrophotometer and ion chromatography were used to determine the enrichment of $\mathrm{NO}_{2}{ }^{-}, \mathrm{NO}_{3}{ }^{-}$, and $\mathrm{SO}_{4}{ }^{2-}$, respectively. Standard titration method using $\mathrm{AgNO}_{3}$ as a reactant solution was used to determine the concentration of $\mathrm{Cl}^{-}$. Traditional titrimetric and ion selective electrode methods were used to determine $\mathrm{HCO}_{3}{ }^{-}$, and $\mathrm{F}^{-}$, respectively. Ion chromatographic-colorimetric analytical principle was used to determine $\mathrm{Cr}^{6+}$.

The evaluation of water suitability for drinking purposes was based on the concentrations of physical and hydrochemical characteristics of the considered samples compared to the limits of physicochemical parameters recommended by the WHO [14,41,42]. The groundwater quality standards set by the Ministry of Health of the People's Republic of China, and the Standardization Administration of the People's Republic of China [43] were also considered in this study.

\subsection{Statistical Analysis and Computing}

In this study, statistical analysis was conducted by using SPSS 25 for Pearson's correlation. Pearson's correlation coefficient $(r)$ helps to quantify the significance of a relationship between two parameters and was widely used in groundwater quality assessment because it gives a quick correlation value. Its mathematical formula is expressed as follows [44]:

$$
r_{x y}=\frac{i=\sum_{i=1}^{n}\left(x_{i}-\bar{x}\right)\left(y_{i}-\bar{y}\right)}{\sqrt{\sum_{i=1}^{n}\left(x_{i}-\bar{x}\right)^{2} \sum_{i=1}^{n}\left(y_{i}-\bar{y}\right)^{2}}}
$$

where, $r_{x y}$ represents the correlation coefficient between the parameters $x$ and $y, n$ denotes the sample size, $x_{i}$ is the individual value of the parameter $x, \bar{x}$ is the mean value of the parameter $x, y_{i}$ stands for the individual value of the parameter $y$, and $\bar{y}$ denotes the mean value of the parameter $y$.

The values of correlation coefficient can be classified as very strong for $r \geq 0.80$, strong for $0.60 \leq r<0.80$, moderate for $0.40 \leq r<0.60$, weak for $0.20 \leq r<0.40$, and very weak for $r<0.20$. In addition, the correlation coefficient is evaluated on the basis of $p$ value. The correlation coefficient is statistically considered as highly significant when $p<0.01$, marginally significant when $p<0.05$, and not significant when $p>0.10$ [44].

For various computing and plots, Microsoft Office 2016 (Excel and Word), Origin 2018, and Grapher 12 were used. Parameter analysis, Piper [45] and Durov [46] diagrams plots were executed using AqQA software. Finally, for mapping, ArcMap 10.3 software was used to locate samples and make a water quality distribution map. This map was obtained using Bayesian Kriging method, which is an automatic Geo-statistical interpolation pack- 
age incorporated in ArcGIS software. The general Kriging equation can be described as follows [47]:

$$
Z^{*}\left(x_{p}\right)=\sum_{i=1}^{n} \lambda_{i} Z\left(x_{i}\right) \text { with } \sum_{i=1}^{n} \lambda_{i}=1
$$

where $\lambda_{i}$ is the Kriging weight; $Z^{*}\left(x_{p}\right)$ estimates the unknown true value.

\subsubsection{Water Quality Index (WQI)}

To evaluate groundwater quality status in the study area, method of water quality index (WQI) was used to integrate comprehensive information through the analysis of physicochemical parameters [31,48-51]. In other words, WQI is a single numerical value obtained by combining a large water quality data [52,53]. First, each chemical parameter is assigned with a weight $\left(w_{i}\right)$, which is determined by affecting the degree of the parameters to groundwater quality. The relative weight $\left(W_{i}\right)$ is computed as:

$$
W_{i}=\frac{w_{i}}{\sum_{i=1}^{n} w_{i}}
$$

where, $W_{i}$ is the relative weight, $w_{i}$ is the assigned weight of each parameter, $n$ is the number of parameters. The value of $w_{i}$ ranges from 1 to 5 according to the impact of the contaminant on human health.

Then, the quality rating scale $\left(q_{i}\right)$ can be computed by:

$$
q_{i}=\frac{C_{i}}{S_{i}} \times 100
$$

where, $q_{i}$ is the quality rating scale, $C_{i}$ is the concentration of each chemical parameter in each water sample in $\mathrm{mg} / \mathrm{L}$, and $S_{i}$ is the standard for each chemical parameter.

To calculate the WQI, $S I_{i}$ has to be determined with the following equations:

$$
\begin{gathered}
S I_{i}=W_{i} \times q_{i} \\
\mathrm{WQI}=\sum S I_{i}
\end{gathered}
$$

where, $S I_{i}$ is the sub-index of the $i$ th parameter and WQI is the water quality index.

The computed WQI values are classified into five categories [15,31,48,54]: excellent water $(<50)$, good water $(50-100)$, poor water $(100-200)$, very poor water $(200-300)$, and unsuitable water $(>300)$.

\subsubsection{Human Health Risk Assessment}

The evaluation of drinking water quality needs to be completed by a health risk assessment as polluted water may cause adverse effects on the human body through water intake and dermal contact $[1,38,42]$. In this study, the potential risks through dermal contact pathway were neglected for non-carcinogenic risk because it is usually low $[27,38,39]$, and water contamination in the study area was not considerably high as listed in Table 1. The risk assessment parameters selected for this study are $\mathrm{NH}_{4}{ }^{+}, \mathrm{NO}_{3}{ }^{-}, \mathrm{NO}_{2}{ }^{-}, \mathrm{F}^{-}$and $\mathrm{Cr}^{6+}$, using the models recommended by the Ministry of Environmental Protection of the P.R. China [30], which are also based on the model recommended by the United States Environmental Protection Agency [29,39]. 
Table 1. Statistical analysis of physicochemical indices for water samples collected in Tongchuan.

\begin{tabular}{|c|c|c|c|c|c|c|c|c|c|c|}
\hline Indices & $\begin{array}{c}\text { Sample } \\
\text { Size }\end{array}$ & Min & $\operatorname{Max}$ & Mean & Median & $\begin{array}{l}\text { Standard } \\
\text { Deviation }\end{array}$ & $\begin{array}{l}\text { Chinese } \\
\text { Standards }\end{array}$ & $\begin{array}{c}\text { WHO } \\
\text { Guidelines }\end{array}$ & $\begin{array}{l}\text { Detection } \\
\text { Limits }\end{array}$ & $\begin{array}{l}\text { \% Exceeding } \\
\text { Standards }\end{array}$ \\
\hline $\mathrm{pH}$ & 48 & 7.05 & 8.39 & 7.77 & 7.79 & 0.30 & $6.5-8.5$ & $6.5-8.5$ & 0.01 & $0^{1,2}$ \\
\hline $\mathrm{TH}$ & 48 & 175 & 731 & 350 & 340 & 115 & 450 & 500 & 1 & $17^{1}, 10.4^{2}$ \\
\hline TDS & 48 & 252 & 1224 & 540 & 512 & 216 & 1000 & 1000 & 5 & $4.2^{1,2}$ \\
\hline $\mathrm{EC}$ & 48 & 519 & 1501 & 870 & 824 & 352 & / & / & 0.01 & / \\
\hline $\mathrm{Na}^{+}$ & 48 & 4.8 & 282.0 & 51.8 & 29.6 & 65.7 & 200 & 200 & 2 & $8.3^{1,2}$ \\
\hline $\mathrm{K}^{+}$ & 48 & 0.88 & 73.10 & 3.99 & 2.04 & 10.36 & / & / & 0.01 & $0^{1,2}$ \\
\hline $\mathrm{Ca}^{2+}$ & 48 & 4.8 & 282.0 & 51.8 & 29.6 & 65.7 & / & / & 0.5 & $36^{2}$ \\
\hline $\mathrm{Cr}^{6+}$ & 48 & BDL & 0.071 & 0.027 & 0.010 & 0.030 & 0.05 & 0.05 & 0.0002 & $6.2^{1,2}$ \\
\hline $\mathrm{Mg}^{2+}$ & 48 & 2.4 & 57.1 & 26.4 & 26.1 & 11.3 & / & / & 0.5 & $4.2^{2}$ \\
\hline $\mathrm{Cl}^{-}$ & 48 & 2.0 & 144.0 & 37.5 & 18.0 & 40.0 & 250 & 250 & 0.5 & $0^{1,2}$ \\
\hline $\mathrm{SO}_{4}{ }^{2-}$ & 48 & 4.80 & 572.00 & 79.19 & 48.00 & 93.76 & 250 & 500 & 0.5 & $2^{1,2}$ \\
\hline $\mathrm{HCO}_{3}^{-}$ & 48 & 201 & 604 & 389 & 384 & 91 & / & / & 1 & / \\
\hline $\begin{array}{l}\mathrm{NO}_{3}{ }^{-}- \\
\mathrm{N}\end{array}$ & 48 & BDL & 262.00 & 32.66 & 16.41 & 49.25 & 20 & 50 & 0.009 & $45.8^{1}, 18.5^{2}$ \\
\hline $\mathrm{NH}_{4}^{+}$ & 48 & BDL & 0.13 & 0.00 & 0.00 & 0.02 & 0.50 & 1.5 & 0.025 & $0^{1,2}$ \\
\hline $\begin{array}{l}\mathrm{NO}_{2}{ }^{-}- \\
\mathrm{N}\end{array}$ & 48 & BDL & 0.46 & 0.07 & 0.01 & 0.13 & 1 & 3 & 0.013 & $0^{1,2}$ \\
\hline $\mathrm{F}^{-}$ & 48 & 0.18 & 2.34 & 0.47 & 0.42 & 0.33 & 1 & 1.5 & 0.01 & $4.2^{1,2}$ \\
\hline
\end{tabular}

${ }^{1}$ Percentage of samples exceeding the P.R. China national standards, ${ }^{2}$ percentage of samples exceeding WHO standards. BDL, below detection limit. All units for all parameter indices are in $\mathrm{mg} / \mathrm{L}$, except for $\mathrm{pH}$ (non-dimensional) and $\mathrm{EC}(\mu \mathrm{S} / \mathrm{cm})$.

According to the references mentioned above, the non-carcinogenic risk through the oral intake pathway is calculated as follows:

$$
\begin{gathered}
\text { Intake }_{\text {oral }}=\frac{C \times I R \times E F \times E D}{B W \times A T} \\
H Q_{\text {oral }}=\frac{\text { Intake }_{\text {oral }}}{R f D_{\text {oral }}}
\end{gathered}
$$

where Intake $e_{\text {oral }}$ denotes the daily average exposure dosage through oral pathway per unit weight $(\mathrm{mg} /(\mathrm{kg} \cdot \mathrm{d})), C$ is the concentration of the parameter in water $(\mathrm{mg} / \mathrm{L})$, and $I R$ represents the ingestion rate of water through drinking (L/d). EF and $E D$ represent the exposure frequency (d/a) and exposure duration (a), respectively. $B W$ and $A T$ are the average body weight $(\mathrm{kg})$ and average time of non-carcinogenic effects (d), respectively.

For this study, the ingestion rate of water used was based on statistical investigation that considers $1.5 \mathrm{~L}$ per day for adults and $0.7 \mathrm{~L}$ per day for children under 12 years old [38]. For non-carcinogenic risk assessment, $E F$ is 365 days per year for both adults and children. $E D$ is 30 years for adults and 12 years for children. $B W$ is $15.9 \mathrm{~kg}$ for children, $56.8 \mathrm{~kg}$ for adults [30]. The average time (AT) for non-carcinogenic effects on children is 4380 days, whereas it is 10,950 days for female and male adults. $H Q_{\text {oral }}$ and $R f D_{\text {oral }}$ represent the hazard quotient and the reference dosage for non-carcinogenic pollutants through the oral exposure pathway $(\mathrm{mg} /(\mathrm{kg} . \mathrm{d}))$, respectively. This study considered the $R f D_{\text {oral }}$ values for $\mathrm{NH}_{4}{ }^{+}$, $\mathrm{NO}_{3}{ }^{-}, \mathrm{NO}_{2}{ }^{-}, \mathrm{F}^{-}$and $\mathrm{Cr}^{6+}$ as $0.97,1.6,0.1,0.04$ and $0.003 \mathrm{mg} /(\mathrm{kg} . \mathrm{d})$, respectively $[1,30,38]$. $H Q$ with a value exceeding 1 indicates a high potential health risk [21]. In addition, $\mathrm{Cr}^{6+}$ can also cause carcinogenic risks through drinking water intake and dermal contact. The total carcinogenic risk is the sum of calculated cancer risk through drinking pathway and that of dermal contact and is calculated as follows $[1,30]$ :

$$
\begin{gathered}
C R_{\text {oral }}=\text { Intake }_{\text {oral }} \times S F_{\text {oral }} \\
C R_{\text {dermal }}=\text { Intake }_{\text {dermal }} \times S F_{\text {dermal }} \\
S F_{\text {dermal }}=\frac{S F_{\text {oral }}}{A B S_{\text {gi }}}
\end{gathered}
$$




$$
C R_{\text {total }}=C R_{\text {oral }}+C R_{\text {dermal }}
$$

where $C R_{\text {oral }}$ represents the carcinogenic risk through the oral exposure pathway. The $C R$ limit is set as $1 \times 10^{-6}$. Intake oral denotes daily average exposure dosage through oral pathway per unit weight $(\mathrm{mg} /(\mathrm{kg} \cdot \mathrm{d})), S F_{\text {oral }}$ is the slope factor for the carcinogenic pollutants $\left(\mathrm{mg} /(\mathrm{kg} \cdot \mathrm{d})^{-1}\right.$. The $S F_{\text {oral }}$ value of $\mathrm{Cr}^{6+}$ is set as $0.5(\mathrm{mg} /(\mathrm{kg} \cdot \mathrm{d}))^{-1}$ by the Ministry of Environmental Protection of the P.R. China [30]. $A B S_{g i}$ is the gastrointestinal absorption factor, and its value is 1 for all contaminants except for $\mathrm{Cr}^{6+}$, with $A B S_{g i}$ equals $0.025[1,30,55]$.

The Intake dermal is calculated as $[1,30,38]$ as in Equations (13)-(15):

$$
\begin{gathered}
\text { Intake }_{\text {dermal }}=\frac{D A \times E V \times S A \times E F \times E D}{B W \times A T} \\
D A=K \times C \times t \times C F \\
S A=239 \times H^{0.417} \times B W^{0.517}
\end{gathered}
$$

where $D A$ and $S A$ are the exposure dosage of every single event in $\mathrm{mg} / \mathrm{cm}^{2}$ and the contacting area skin surface $\left(\mathrm{cm}^{2}\right)$, respectively. $E V$ is the daily exposure frequency of dermal contact set at 1 for this study. ED is the exposure duration for carcinogenic risk, different from non-carcinogenic risk, and is set as 25,550 days for both adults and children $K$ is the coefficient of skin permeability $(0.001 \mathrm{~cm} / \mathrm{h}), t$ is the contact duration, which is set as $0.4 \mathrm{~h} /$ day for both adults and children $[1,38]$. $C F$ is a conversion factor that equals 0.001 , and $H$ denotes the average height of the population estimated at $165.3 \mathrm{~cm}$ for males, $153.4 \mathrm{~cm}$ for females and 99.4 for children [1].

\section{Results and Discussion}

\subsection{Physicochemical Parameters}

Groundwater quality data were first checked for reliability and accuracy by calculating the correlation between EC and the sum of cations on one hand and with the sum of anions on the other hand. The results show a good correlation with $\mathrm{R}^{2}>0.8$ (Figure 2a,b. The reliability of groundwater quality data was also checked by the ion charge balance between cations and anions as follows:

$$
E(\%)=\frac{N_{c}-N_{a}}{N_{c}+N_{a}} \times 100
$$

where, $N_{c}$ and $N_{a}$ denote total concentrations of cations and anions of a sample in meq/L, respectively. The biggest value of $E$ was $3.14 \%$, which indicated that the samples were reliable, as the $E$ value was between $-5 \%$ and $+5 \%$.

The physicochemical indices of groundwater samples were statistically analyzed, and the results are listed in Table 1. The $\mathrm{pH}$ values in this study ranged from 7.05 to 8.39, which were within the guidelines set by the WHO [42] for drinking water (6.5 to 8.5). Hem [56] concluded that the $\mathrm{pH}$ of groundwater was controlled by the equilibrium of $\mathrm{CO}_{3}{ }^{2-}, \mathrm{CO}_{2}$ and $\mathrm{HCO}_{3}{ }^{-}$, and interpreted the chemical characteristics of natural water. The mean $\mathrm{pH}$ value of groundwater samples was 7.77, which was suitable for drinking purpose. Mechenich and Andrews [57] considered the range of $\mathrm{pH}$ values from 7.5-8.3 as an ideal values range for drinking water. Thus, it can be assumed that $\mathrm{pH}$ values for drinking water in Tongchuan City are good and ideal. However, 12 samples ( $25 \%$ of the total samples) showed slight alkalinity of the drinking water in the study area with $\mathrm{pH}$ ranging from 8 to 8.39 . Alkalinity is not only associated with high $\mathrm{pH}$ values, but also with hardness and excessive TDS [33]. 


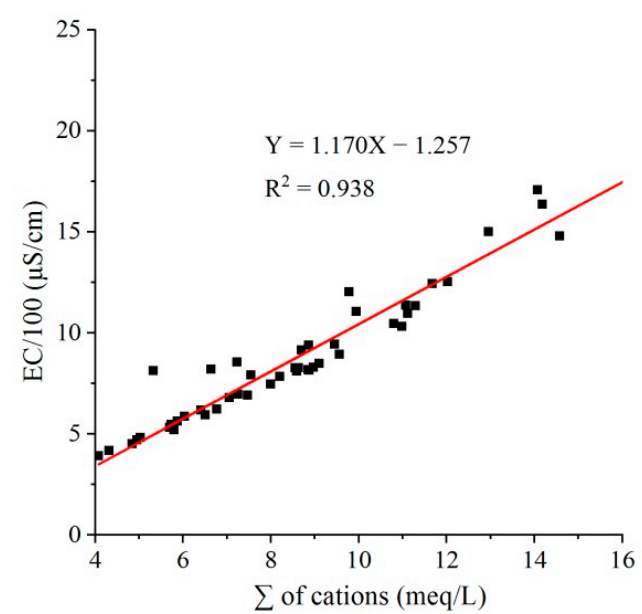

(a)

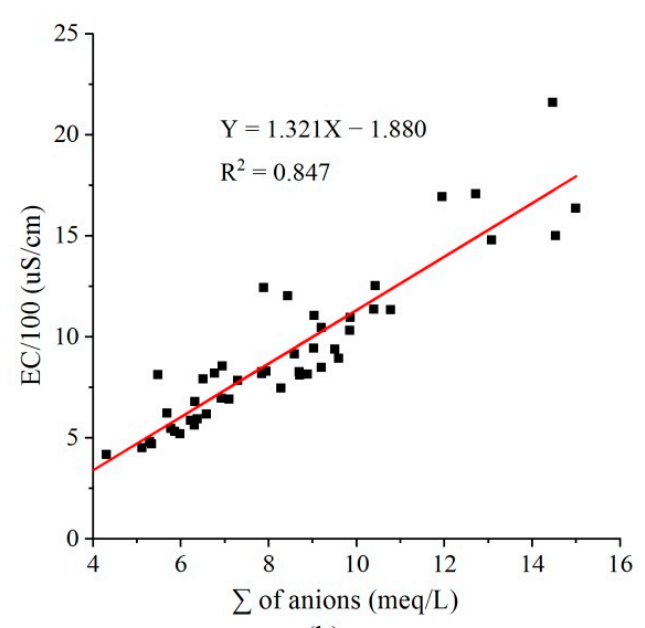

(b)

Figure 2. Ionic balance of groundwater data: (a) $\Sigma$ of cations vs. EC/100; (b) $\Sigma$ of anions vs. EC/100.

According to the average $\mathrm{pH}$ value, the groundwater in the study area can be used as drinking water. However, when comparing the detected TDS and TH values with the drinking water standards, there were two samples (4.2\%) with TDS exceeding $1000 \mathrm{mg} / \mathrm{L}$, and five samples $(10.4 \%)$ with TH exceeding $500 \mathrm{mg} / \mathrm{L}$. At the same time, referring to the drinking water quality guidelines recommended by the Ministry of Health of the People's Republic of China, there were eight samples (17\%) whose TH exceeded $450 \mathrm{mg} / \mathrm{L}$. This would be considered as hard water [1]. However, this classification is far different from the drinking water classification early made by Freeze and Cherry [58] (Table 2) based on $\mathrm{TH}$. The groundwater classification on the basis of TDS and TH $[14,31,58,59]$ in Tongchuan are as follows (Table 2): $35.4 \%$ and $64.6 \%$ of samples were hard water or very hard water; $47.9 \%$ were desirable and permissible for drinking; $95.8 \%$ were fresh water and $4.2 \%$ were brackish.

Table 2. TDS and TH-based classification of groundwater for drinking purpose in Tongchuan.

\begin{tabular}{cccc}
\hline Parameters & Range & Water Type & \% of Samples \\
\hline \multirow{3}{*}{ TH } & $<75$ & Soft & 0 \\
& $75-150$ & Moderately hard & 0 \\
& $150-300$ & Hard & 35.4 \\
& $>300$ & Very hard & 64.6 \\
\hline \multirow{2}{*}{ TDS } & $<500$ & Desirable for drinking & 47.9 \\
& $500-1000$ & Permissible for drinking & 47.9 \\
& $<1000$ & Fresh water & 95.8 \\
& $>1000$ & Brackish & 4.2 \\
\hline
\end{tabular}

In addition, the $\mathrm{TH}$ values of water are the measures of the dissolved $\mathrm{Ca}^{2+}$ and $\mathrm{Mg}^{2+}$ content, which are expressed in $\mathrm{CaCO}_{3} \mathrm{mg} / \mathrm{L}$ and can be associated $\mathrm{EC}$, which is normally twice the hardness for uncontaminated water [23,57]. Otherwise, if it is higher than that proportion, it provides information on the presence of components such as $\mathrm{Na}^{+}, \mathrm{Cl}^{-}$or $\mathrm{SO}_{4}{ }^{2-}$ [57]. Through the analysis of the physical and chemical indicators of the samples in the study area, the average values of EC and TH were $869.75 \mu \mathrm{S} / \mathrm{cm}$ and $349.94 \mathrm{mg} / \mathrm{L}$, respectively, and the conductivity was greater than two times of the $\mathrm{TH}$, which indicated that slightly high concentrations of $\mathrm{Na}^{+}, \mathrm{Cl}^{-}$, and $\mathrm{SO}_{4}{ }^{2-}$ were in some groundwater samples.

The order of major cations in the groundwater samples from the study area was $\mathrm{Ca}^{2+}$ $>\mathrm{Na}^{+}>\mathrm{Mg}^{2+}>\mathrm{K}^{+}$, with average values of $96.62,51.81,26.43$, and $3.99 \mathrm{mg} / \mathrm{L}$, respectively. The order of major anions of the samples was $\mathrm{HCO}_{3}{ }^{-}>\mathrm{SO}_{4}{ }^{2-}>\mathrm{Cl}^{-}$, with average values of $389.29,79.19$, and $37.49 \mathrm{mg} / \mathrm{L}$, respectively. 
Indicated by the detected results of the samples, there was no $\mathrm{HN}_{4}{ }^{+}$contamination in the groundwater of the study area because the maximum $\mathrm{HN}_{4}{ }^{+}$concentration of the samples $(0.13 \mathrm{mg} / \mathrm{L})$ was in the range of natural levels of $\mathrm{HN}_{4}{ }^{+}$in groundwater (below $0.2 \mathrm{mg} / \mathrm{L}$ ), according to WHO [42]. The concentration of $\mathrm{HN}_{4}{ }^{+}$in water is an indicator of possible bacterial, sewage, landfill, and animal waste pollution [30]. The concentration of $\mathrm{Cl}^{-}$was not excessive in the analyzed samples from drinking water as it ranged from 2 to $144 \mathrm{mg} / \mathrm{L}$. The WHO [42] has not set a health-based guideline value for $\mathrm{Cl}^{-}$, but a concentration exceeding $250 \mathrm{mg} / \mathrm{L}$ can cause the water to be unsuitable for drinking as high $\mathrm{Cl}^{-}$waters have a laxative effect for some people $[33,55]$.

Although there is no health-based guideline value for $\mathrm{Na}^{+}$in potable water according to WHO [42], if its concentration exceeds $200 \mathrm{mg} / \mathrm{L}$, it may taste bad, and excessive intake may cause hypertension [18]. $\mathrm{Na}^{+}$concentrations of four samples $(8.3 \%$ of the total samples) slightly exceeded that threshold for the present study. A value of $\mathrm{K}^{+}$exceeding $12 \mathrm{mg} / \mathrm{L}$ in drinking water gives it a bitter taste [31]. In this study, only two samples (4.2\%) exceeded this permissible limit. $\mathrm{SO}_{4}{ }^{2-}$ was not excessive, except in one sample, where its concentration exceeded $(572 \mathrm{mg} / \mathrm{L})$ the $\mathrm{SO}_{4}{ }^{2-}$ concentration limit proposed by WHO [30] for potable water, which is $500 \mathrm{mg} / \mathrm{L}$.

To check the simultaneous occurrence of $\mathrm{NO}_{3}{ }^{-}$and $\mathrm{NO}_{2}{ }^{-}$in drinking water, the sum of the ratios of the concentration of each over its guideline value $(G V)$ should not exceed 1 [42]:

$$
\frac{C_{\text {nitrate }}}{G V_{\text {nitrate }}}+\frac{C_{\text {nitrite }}}{G V_{\text {nitrite }}} \leq 1
$$

where $C_{\text {nitrate }}$ is the concentration of $\mathrm{NO}_{3}{ }^{-}, C_{\text {nitrite }}$ is the concentration of $\mathrm{NO}_{2}{ }^{-}$, and $G V_{\text {nitrate }}$ and $G V_{\text {nitrite }}$ are the guideline values of $\mathrm{NO}_{3}{ }^{-}$and $\mathrm{NO}_{2}{ }^{-}$, respectively.

The application of this formula reveals that $16.6 \%$ of the groundwater samples were in the situation of simultaneous occurrence of $\mathrm{NO}_{3}{ }^{-}$and $\mathrm{NO}_{2}{ }^{-}$in drinking water. Furthermore, in the presence of microbial contamination, especially due to fecal contamination in drinking water, the health risk to infants is high [42].

In this study, $6.2 \%$ of the groundwater samples slightly exceeded the guideline value of permissible concentration in drinking water, which is $0.05 \mathrm{mg} / \mathrm{L}$ [43]. Fluoride is important for drinking water, with a concentration ranging from 0.7 to $1.2 \mathrm{mg} / \mathrm{L}$, as it protects against dental cavities and strengthens the bones. When $\mathrm{F}^{-}$concentration exceeds $1.5 \mathrm{mg} / \mathrm{L}$, it causes teeth mottling, fluorosis or discoloration $[33,42,60,61]$ as well as other health problems such as nervous system harm and urinary tract disease [62,63]. Although there were two samples with $\mathrm{F}^{-}$concentration exceeding $1.5 \mathrm{mg} / \mathrm{L}$, most of the samples $(83.3 \%)$ were associated with low $\mathrm{F}^{-}$concentrations below $0.7 \mathrm{mg} / \mathrm{L}$. Therefore, to ensure the good health of the population in Tongchuan City, $\mathrm{F}^{-}$should be added in drinking water to the majority of wells and be reduced in a few wells to avoid potential health hazards. In addition, $50 \mathrm{mg} / \mathrm{L}$ of the guideline value for $\mathrm{NO}_{3}{ }^{-}$was established by WHO [42] to protect the most sensitive populations. However, this population must be free of adverse health effects such as methemoglobinemia and thyroid effects at a concentration below $50 \mathrm{mg} / \mathrm{L}$ of $\mathrm{NO}_{3}{ }^{-}$. This health risk can seriously affect bottle-fed infants when mathemoglobinemia is complicated by the presence of microbial contamination and subsequent gastrointestinal infection that manifests as diarrhea.

Excessive boiling of water for microbiological safety purposes may increase the concentration of $\mathrm{NO}_{3}{ }^{-}$. Water for drinking should be heated until it reaches a rolling boil [42] For $\mathrm{NO}_{3}{ }^{-}, 45.8 \%$ of the samples exceeded the limits $(20 \mathrm{mg} / \mathrm{L})$ set by the Ministry of Health of the P.R. China [43].

\subsection{Relationship between Depth of Wells and the Concentration of Physicochemical Parameters}

Figure 3 shows the scatter plot of $\mathrm{F}^{-}, \mathrm{Na}^{+}$, and $\mathrm{NO}_{2}{ }^{-}$concentrations with groundwater level depth. It shows that the water samples were mostly concentrated in the shallow depth (less than $30 \mathrm{~m}$ ). Fluoride is present in lower concentrations in shallow groundwater than in deep groundwater. This is because the dissolution of F-containing minerals such as 
fluorite is an important source of $\mathrm{F}^{-}$in groundwater of the study area, and the amount of fluorite is higher in the deep aquifer. The alkaline $\mathrm{pH}$ can influence $\mathrm{CaF}_{2}$ activity and favors the mobilization of $\mathrm{F}^{-}$from soil and weathered rocks into groundwater. This assumption was also formulated by other researchers [64-66]. The enrichment of $\mathrm{F}^{-}$can also be influenced by the ratio between $\mathrm{HCO}_{3}{ }^{-}, \mathrm{Na}^{+}$and $\mathrm{Ca}^{2+}$ in groundwater, as confirmed by Saxena and Ahmed [67], Rango et al. [68], and Kimambo et al. [64]. $\mathrm{Na}^{+}$concentration is lower in the shallow aquifer, which also supports the phenomenon of low $\mathrm{F}^{-}$in shallow groundwater.

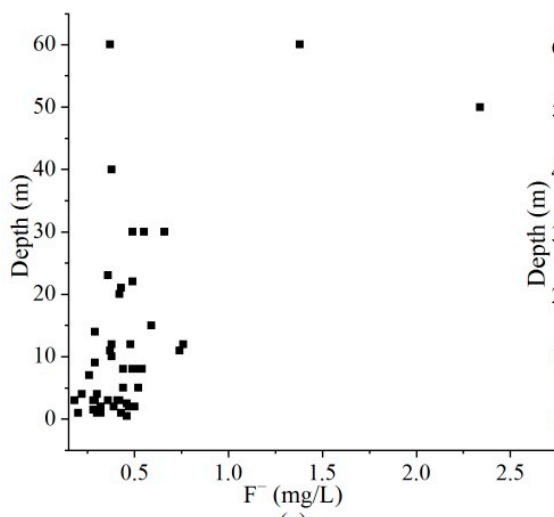

(a)

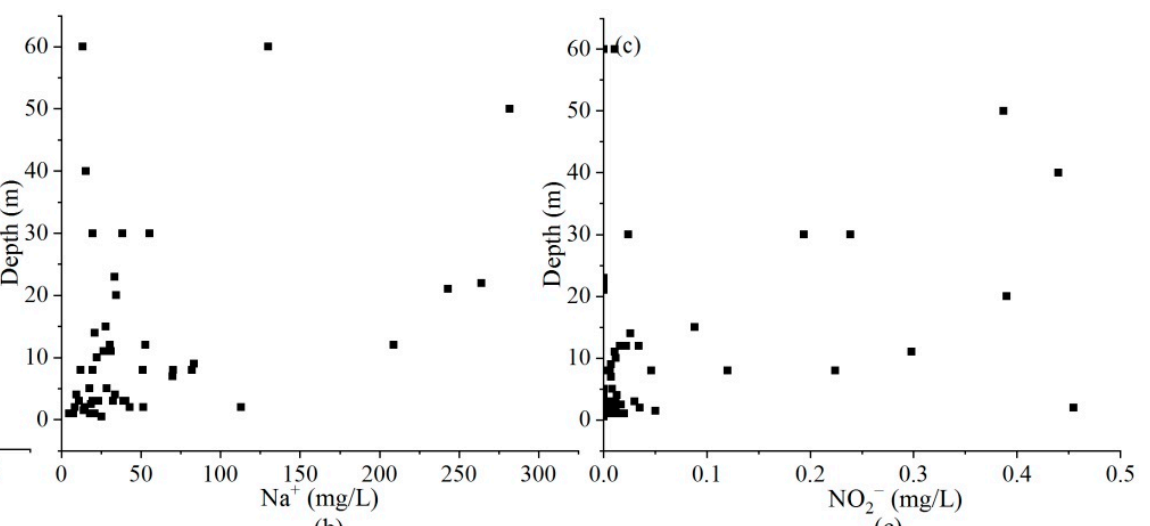

(b)

Figure 3. Relationship between fluoride and depth (a), sodium and depth (b), nitrite and depth (c).

Samples with low concentration of $\mathrm{NO}_{2}{ }^{-}$are usually observed in the shallow aquifer than in the deep aquifer. This may be due to the oxidation environment in the shallow aquifer that favors the transformation of $\mathrm{NO}_{2}{ }^{-}$to $\mathrm{NO}_{3}{ }^{-}$. Numerous studies have shown that human activities such as agriculture, industry, domestic sewage, landfills, and household waste influences shallow groundwater quality $[1,32,69]$.

\subsection{Hydrochemical Types of Groundwater}

The Durov diagram depicted in Figure $4 \mathrm{~b}$ reveals that most of the samples are concentrated in the field of $\mathrm{HCO}_{3}-\mathrm{Ca}$ type and combined $\mathrm{HCO}_{3} \cdot \mathrm{SO}_{4}-\mathrm{Ca} \cdot \mathrm{Mg}$ type. This situation may result from the dissolution of $\mathrm{CO}_{3}{ }^{-}$minerals and $\mathrm{F}^{-}$[68]. As also discussed by Ravikumar et al. [70] and Lloyd and Heathcote [71], the $\mathrm{HCO}_{3}$-Ca dominant frequently indicates that recharging waters in limestone and sandstone is associated with dolomite. To assess the water quality, a Piper diagram (Figure 4a) was used to characterize the hydrogeochemical facies of groundwater samples from the study area. The Piper plot shows that $\mathrm{Ca}^{2+}, \mathrm{Na}^{+}$, and $\mathrm{Mg}^{2+}$ are dominant cations in the region. Conversely, $\mathrm{HCO}_{3}{ }^{-}$and $\mathrm{SO}_{4}{ }^{2-}$ dominate the facies, while $\mathrm{Cl}^{-}$is quasi-inexistent. The general classification of all samples shows $81.25 \% \mathrm{Ca} \cdot \mathrm{Mg}-\mathrm{HCO}_{3}, 8 \% \mathrm{Ca} \cdot \mathrm{Mg}-\mathrm{SO}_{4} \cdot \mathrm{Cl}, 4.1 \% \mathrm{Na}-\mathrm{Cl}$ and $6.25 \% \mathrm{Na}-\mathrm{HCO}_{3}$ water type (Figure $4 \mathrm{a}$ ). The dominant $\mathrm{Ca} \cdot \mathrm{Mg}-\mathrm{HCO}_{3}$ type may indicate that the influence of dissolution on groundwater chemistry is more considerable, and it signifies the dominance of alkaline earths over alkalis; weak acids exceed strong acids. This observation was also found by other researchers, notably Xu et al. [72], Ravikumar et al. [70] and Singh et al. [16]. 


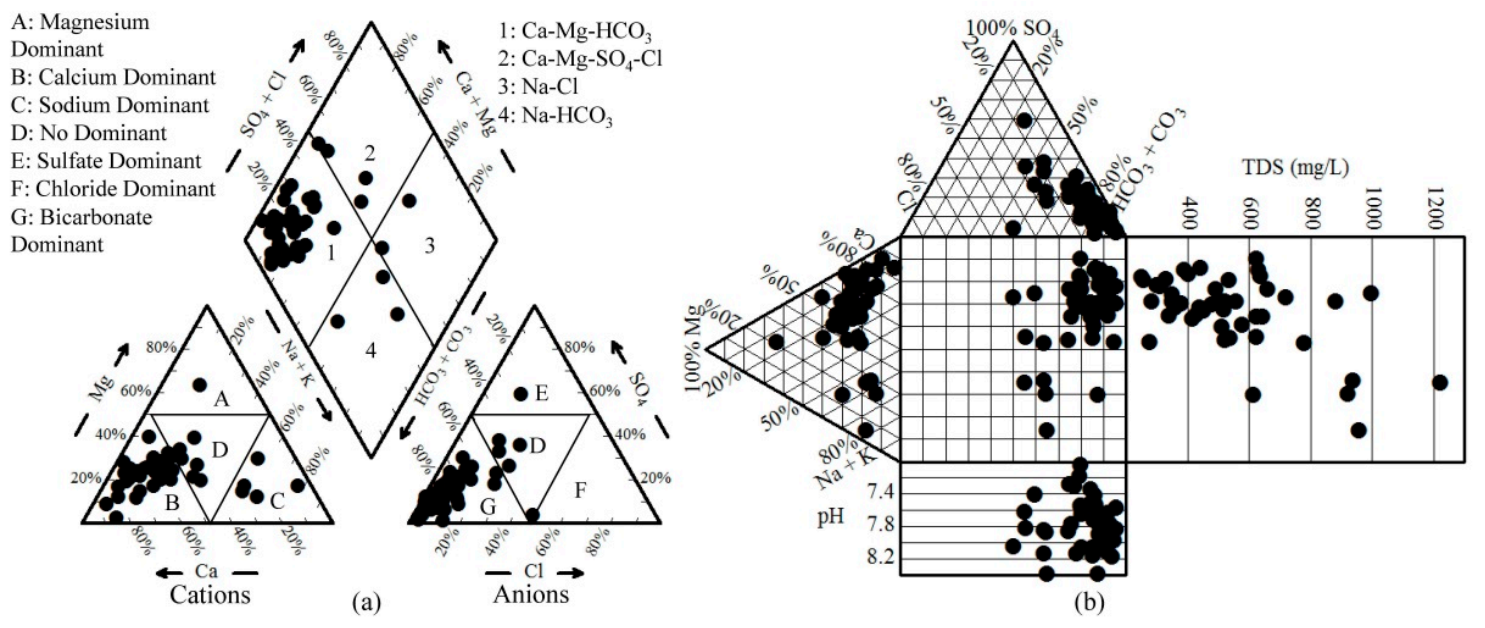

Figure 4. Piper (a) and Durov (b) diagrams showing the samples classifications.

\subsection{Hydrochemical Correlation Analysis of Water Quality}

To better understand the major hydrogeochemical processes that control the chemical characteristics, it is necessary to carry out a Pearson's correlation analysis that shows the relationship between each pair of physicochemical indices [39,73]. Table 3 gives the correlation values of physicochemical parameters of water samples.

Table 3. Pearson correlation matrix between physicochemical parameters of water samples.

\begin{tabular}{|c|c|c|c|c|c|c|c|c|c|c|c|c|c|c|c|c|}
\hline & $\mathbf{K}^{+}$ & $\mathrm{Na}^{+}$ & $\mathrm{Ca}^{2+}$ & $\mathrm{Mg}^{2+}$ & $\mathrm{NH}_{4}{ }^{+}$ & $\mathrm{Cl}^{-}$ & $\mathrm{SO}_{4}{ }^{2-}$ & $\mathrm{HCO}_{3}{ }^{-}$ & $\mathrm{NO}_{3}{ }^{-}$ & $\mathrm{NO}_{2}{ }^{-}$ & TDS & TH & $\mathrm{pH}$ & $\mathbf{F}^{-}$ & EC & $\mathrm{Cr}^{6+}$ \\
\hline $\mathrm{K}^{+}$ & 1 & -0.030 & 0.164 & 0.056 & 0.099 & 0.036 & 0.061 & 0.150 & 0.163 & -0.011 & 0.145 & 0.166 & -0.110 & -0.054 & 0.137 & -0.06 \\
\hline $\mathrm{Na}^{+}$ & & 1 & -0.186 & 0.313 & -0.015 & 0.727 & 0.745 & 0.360 & -0.097 & 0.108 & 0.765 & -0.036 & 0.287 & 0.602 & 0.742 & 0.375 \\
\hline $\mathrm{Ca}^{2+}$ & & & 1 & 0.103 & 0.346 & 0.255 & 0.225 & 0.334 & 0.521 & 0.017 & 0.436 & 0.916 & -0.721 & -0.500 & 0.469 & -0.354 \\
\hline $\mathrm{Mg}^{2+}$ & & & & 1 & 0.395 & 0.525 & 0.342 & 0.271 & 0.509 & 0.335 & 0.551 & 0.494 & 0.143 & 0.188 & 0.488 & 0.23 \\
\hline $\mathrm{NH}_{4}{ }^{+}$ & & & & & 1 & 0.311 & 0.103 & 0.072 & 0.431 & 0.482 & 0.295 & 0.462 & -0.115 & -0.051 & 0.277 & -0.06 \\
\hline $\mathrm{Cl}^{-}$ & & & & & & 1 & 0.623 & 0.243 & 0.456 & 0.304 & 0.860 & 0.436 & 0.083 & 0.343 & 0.857 & 0.14 \\
\hline $\mathrm{SO}_{4}{ }^{2-}$ & & & & & & & 1 & 0.148 & -0.000 & -0.025 & 0.804 & 0.335 & -0.118 & 0.107 & 0.804 & -0.02 \\
\hline $\mathrm{HCO}_{3}$ & & & & & & & & 1 & 0.012 & 0.054 & 0.504 & 0.401 & -0.223 & 0.230 & 0.469 & 0.340 \\
\hline $\mathrm{NO}_{3}{ }^{-}$ & & & & & & & & & 1 & 0.364 & 0.395 & 0.662 & -0.108 & -0.045 & 0.384 & -0.01 \\
\hline $\mathrm{NO}_{2}{ }^{-}$ & & & & & & & & & & 1 & 0.207 & 0.151 & 0.259 & 0.347 & 0.141 & 0.343 \\
\hline TDS & & & & & & & & & & & 1 & 0.604 & -0.123 & 0.274 & 0.980 & 0.18 \\
\hline $\mathrm{TH}$ & & & & & & & & & & & & 1 & -0.571 & -0.360 & 0.607 & -0.22 \\
\hline $\mathrm{pH}$ & & & & & & & & & & & & & 1 & 0.598 & -0.148 & 0.379 \\
\hline $\mathrm{F}^{-}$ & & & & & & & & & & & & & & 1 & 0.209 & 0.703 \\
\hline EC & & & & & & & & & & & & & & & 1 & 0.10 \\
\hline $\mathrm{Cr}^{6+}$ & & & & & & & & & & & & & & & & 1 \\
\hline
\end{tabular}

Bold number indicates that the correlation is significant at the 0.05 level (two-tailed). Italic number indicates that the correlation is significant at the 0.01 level (two-tailed).

As shown in Table 3, there is a strong correlation, which is explained by ions exchange between TDS and EC with $r=0.980$ at the level of $p>0.01, \mathrm{Ca}^{2+}$ content and TH with $r=0.916$ at the level of $p>0.01, \mathrm{Cl}^{-}$and TDS with $r=0.860$ at the level of $p>0.01, \mathrm{Cl}^{-}$and EC with $r=0.857$ at the level of $p>0.01$, and $\mathrm{SO}_{4}{ }^{2-}$ correlates with TDS and EC with both $r=0.804$ at the level of $p>0.01$. In addition, a strong correlation exists between $\mathrm{Na}^{+}$and TDS, $\mathrm{SO}_{4}{ }^{2-}$, EC, and $\mathrm{Cl}^{-}$with $r=0.765,0.745,0.742$, and 0.727 , respectively. Furthermore, there is a strong relationship between $\mathrm{NO}_{3}{ }^{-}$and TH with $r=0.662$ at the level of $p>0.01$, $\mathrm{Cl}^{-}$and $\mathrm{SO}_{4}{ }^{2-}$ with $r=0.623$ at the level of $p>0.01$, TH and EC with $r=0.607$ at the level of $p>0.01$, and $\mathrm{Na}^{+}$and $\mathrm{F}^{-}$with $r=0.602$ at the level of $p>0.01$.

Although all the aforementioned correlations between parameters are positive, there is a strong negative correlation between $\mathrm{Ca}^{2+}$ and $\mathrm{pH}$ with $r=-0.721$ at the level of $p>0.01$. $\mathrm{Ca}^{2+}$ and $\mathrm{Mg}^{2+}$ are significantly correlated to TH because they contribute to the water hardness. 
A strong correlation between $\mathrm{Cr}^{6+}$ and $\mathrm{F}^{-}$with $r=0.703$ at level $p>0.05$, which may be due to the oxidation mechanism of $\mathrm{Cr}^{3+}$ to $\mathrm{Cr}^{6+}$ in the presence of $\mathrm{F}^{-}$in groundwater, was observed. Finally, a significant correlation between $\mathrm{Cr}^{6+}$ and both $\mathrm{Na}^{+}$and $\mathrm{pH}$ was also noticeable. All these parameters may have triggered the mobilization of $\mathrm{Cr}$ in the groundwater system [29].

\subsection{Water Quality Index Assessment}

Table 4 shows the weight assigned to each parameter, and the relative weights are calculated using Formula (3).

Table 4. Relative weight of physicochemical parameters. All units for all parameter indices are in $\mathrm{mg} / \mathrm{L}$, except $\mathrm{pH}$ (non-dimensional).

\begin{tabular}{cccc}
\hline Parameters & Chinese Standards & Weight $\left(w_{i}\right)$ & Relative Weight $\left(\boldsymbol{W}_{\boldsymbol{i}}\right)$ \\
\hline $\mathrm{pH}$ & $6.5-8.5$ & 4 & 0.0714 \\
$\mathrm{TH}$ & 450 & 5 & 0.0893 \\
$\mathrm{TDS}$ & 1000 & 5 & 0.0893 \\
$\mathrm{Na}^{+}$ & 200 & 2 & 0.0536 \\
$\mathrm{Cr}^{6+}$ & 0.05 & 5 & 0.0893 \\
$\mathrm{Cl}^{-}$ & 250 & 2 & 0.0357 \\
$\mathrm{SO}_{4}{ }^{2-}$ & 250 & 4 & 0.0714 \\
$\mathrm{NO}_{3}{ }^{-}$ & 20 & 5 & 0.0893 \\
$\mathrm{NH}_{4}{ }^{-}$ & 0.5 & 5 & 0.0893 \\
$\mathrm{NO}_{2}^{-}$ & 1 & 4 & 0.0893 \\
$\mathrm{~F}^{-}$ & 1 & 4 & 0.0714 \\
\hline
\end{tabular}

Table 5 lists the water quality assessment results. As shown in Table 5, 37 of the samples (77.1\%) are of excellent quality, 9 samples (18.7\%) are of good quality, and 2 samples $(4.2 \%)$ are of poor quality. The most significant parameters affecting the water quality in the study area are $\mathrm{NO}_{3}{ }^{-}, \mathrm{F}^{-}$, and $\mathrm{Cr}^{6+}$.

Water without excellent quality is dominated by wells with low depth represented by samples TW1-052, TW1-047, TW1-041, TW2-021, TW2-66 and TW2-67 with 2, 3, 2, 3, 10, and $8 \mathrm{~m}$, respectively.

The contamination source of the wells represented by samples TW1-052, TW1-047, TW1-041 might be the ravines situated nearby. These ravines may bring contaminated water that leaks in the phreatic and shallow aquifer. The other concerned wells with low depth were possibly contaminated by human activities, as they are located in residential and agricultural areas.

As depicted in Figure 5, a major part of Tongchuan is dominated by excellent water and can be used for drinking purpose. However, in some towns such as Yuhua, Wangshiao, and Chenlu, for example, groundwater quality is not suitable for drinking. Therefore, water needs pretreatment before drinking, and taking effective measures to prevent groundwater pollution is imperative. Low deep wells should also be drilled deeply to avoid contamination by surface water leakage and pollution caused by human activities.

\subsection{Health Risk Assessment}

Table 6 presents the calculated health risk to adults and children when they are exposed to the contaminants in groundwater through drinking water intake. The total health risk due to contaminated drinking water intake ranges from 0.21 to 4.71 , with a mean of 0.89 for adults. For children, the health risk is evaluated through the hazard quotient ranged from 0.35 to 7.85 with a mean of 1.52. Considering that $H Q>1$ for non-carcinogenic risk indicates high potential health risk [1], water from wells represented by samples TW1008, TW1-009, TW1-037, TW1-041, TW1-047, TW1-049 to TW1-054, TW1-059 to TW1-061, TW2-014 to TW2-067 was not safe, especially for children. 
Table 5. Water quality index values and water types of the samples.

\begin{tabular}{|c|c|c|c|c|c|c|c|c|}
\hline Samples & WQI & $\begin{array}{c}\text { Water } \\
\text { Quality }\end{array}$ & Samples & WQI & $\begin{array}{c}\text { Water } \\
\text { Quality }\end{array}$ & Samples & WQI & $\begin{array}{c}\text { Water } \\
\text { Quality }\end{array}$ \\
\hline TW1-002 & 15.02 & Excellent & TW1-038 & 22.99 & Excellent & TW1-060 & 51.38 & Good \\
\hline TW1-003 & 14.75 & Excellent & TW1-039 & 13.70 & Excellent & TW1-061 & 26.24 & Excellent \\
\hline TW1-004 & 16.73 & Excellent & TW1-041 & 51.76 & Good & TW2-014 & 46.40 & Excellent \\
\hline TW1-005 & 20.98 & Excellent & TW1-043 & 57.22 & Good & TW2-018 & 64.38 & Good \\
\hline TW1-007 & 25.96 & Excellent & TW1-046 & 24.53 & Excellent & TW2-021 & 187.45 & Poor \\
\hline TW1-008 & 39.18 & Excellent & TW1-047 & 76.75 & Good & TW2-022 & 44.63 & Excellent \\
\hline TW1-009 & 41.89 & Excellent & TW1-048 & 18.71 & Excellent & TW2-037 & 17.05 & Excellent \\
\hline TW1-010 & 12.24 & Excellent & TW1-049 & 51.04 & Good & TW2-042 & 32.21 & Excellent \\
\hline TW1-012 & 30.86 & Excellent & TW1-050 & 16.25 & Excellent & TW2-043 & 13.98 & Excellent \\
\hline TW1-013 & 12.02 & Excellent & TW1-051 & 14.03 & Excellent & TW2-044 & 33.59 & Excellent \\
\hline TW1-014 & 18.41 & Excellent & TW1-052 & 166.56 & Poor & TW2-045 & 39.97 & Excellent \\
\hline TW1-023 & 13.20 & Excellent & TW1-053 & 39.17 & Excellent & TW2-057 & 23.71 & Excellent \\
\hline TW1-025 & 14.05 & Excellent & TW1-054 & 59.63 & Good & TW2-058 & 19.68 & Excellent \\
\hline TW1-032 & 16.13 & Excellent & TW1-055 & 25.67 & Excellent & TW2-066 & 54.70 & Good \\
\hline TW1-036 & 21.27 & Excellent & TW1-058 & 23.88 & Excellent & TW2-067 & 50.18 & Good \\
\hline TW1-037 & 38.25 & Excellent & TW1-059 & 31.14 & Excellent & TW2-069 & 15.90 & Excellent \\
\hline
\end{tabular}

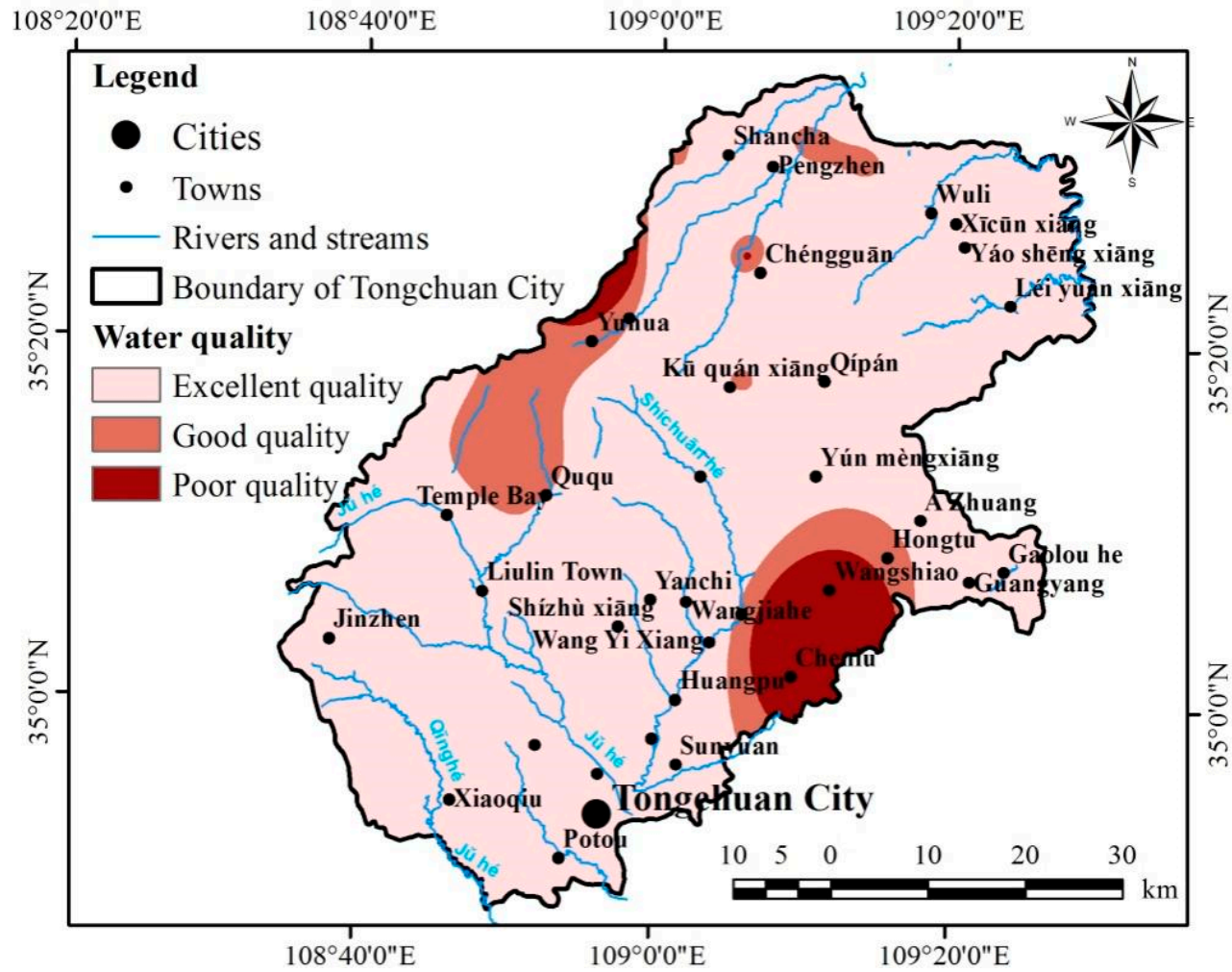

Figure 5. Water quality distribution in Tongchuan City.

As shown in Figure 6, $\mathrm{NO}_{3}{ }^{-}$contributes a considerable amount to non-carcinogenic risk for both adults and children and is followed by $\mathrm{F}^{-}, \mathrm{Cr}^{6+}$, and lastly, by $\mathrm{NO}_{2}{ }^{-}$.

The respective HQ mean values for adults are $0.54,0.31,0.02,0.02$, and $0.90,0.52$, 0.07 , and 0.03 for children. $\mathrm{HN}_{4}{ }^{+}$has zero contribution to health risk in this study area for both adults and children. High nitrate health risk is probably due to the anthropogenic activities, especially fertilizers in agriculture [21]. In addition, Wei et al. [34] reported that $\mathrm{NO}_{3}{ }^{-}$pollution was a major environmental geological problem in the groundwater for this region. Overall, $27.1 \%$ and $54.2 \%$ of the samples present a health risk through drinking water intake for adults and children, respectively. 
Table 6. Calculated hazard quotient (HQ) of non-carcinogenic risk for adults and children.

\begin{tabular}{|c|c|c|c|c|c|c|c|c|c|c|c|c|}
\hline \multirow{2}{*}{ Samples } & \multicolumn{6}{|c|}{ Adults } & \multicolumn{6}{|c|}{ Children } \\
\hline & $\mathrm{HQ}_{\mathrm{NH} 4}{ }^{+}$ & $\mathrm{HQ}_{\mathrm{NO}^{-}}{ }^{-}$ & $\mathrm{HQ}_{\mathrm{NO} 2}^{-}$ & $\mathrm{HQ}_{\mathrm{F}}{ }^{-}$ & $\mathrm{HQ}_{\mathrm{Cr}}{ }^{6+}$ & $\mathrm{HQ}_{\mathrm{T}}$ & $\mathrm{HQ}_{\mathrm{NH} 4}{ }^{+}$ & $\mathrm{HQ}_{\mathrm{NO}^{2-}}{ }^{2-}$ & $\mathrm{HQ}_{\mathrm{NO} 2}{ }^{-}$ & $\mathrm{HQ}_{\mathrm{F}}{ }^{-}$ & $\mathrm{HQ}_{\mathrm{Cr}}{ }^{6+}$ & $\mathrm{HQ}_{\mathrm{T}}$ \\
\hline TW1-002 & 0.00 & 0.06 & 0.00 & 0.15 & 0.00 & 0.21 & 0.00 & 0.10 & 0.01 & 0.24 & 0.00 & 0.35 \\
\hline TW1-003 & 0.00 & 0.06 & 0.00 & 0.34 & 0.00 & 0.41 & 0.00 & 0.10 & 0.00 & 0.57 & 0.00 & 0.68 \\
\hline TW1-004 & 0.00 & 0.00 & 0.12 & 0.25 & 0.11 & 0.48 & 0.00 & 0.00 & 0.19 & 0.42 & 0.21 & 0.82 \\
\hline TW1-005 & 0.00 & 0.00 & 0.01 & 0.34 & 0.00 & 0.36 & 0.00 & 0.00 & 0.02 & 0.57 & 0.00 & 0.59 \\
\hline TW1-008 & 0.00 & 0.37 & 0.00 & 0.31 & 0.00 & 0.68 & 0.00 & 0.61 & 0.01 & 0.52 & 0.00 & 1.13 \\
\hline TW1-009 & 0.00 & 0.26 & 0.01 & 0.50 & 0.00 & 0.76 & 0.00 & 0.43 & 0.01 & 0.84 & 0.00 & 1.28 \\
\hline TW1-010 & 0.00 & 0.00 & 0.00 & 0.27 & 0.00 & 0.27 & 0.00 & 0.00 & 0.00 & 0.45 & 0.00 & 0.45 \\
\hline TW1-012 & 0.00 & 0.11 & 0.00 & 0.28 & 0.00 & 0.39 & 0.00 & 0.18 & 0.00 & 0.47 & 0.00 & 0.65 \\
\hline TW1-013 & 0.00 & 0.07 & 0.00 & 0.26 & 0.00 & 0.33 & 0.00 & 0.12 & 0.00 & 0.43 & 0.00 & 0.55 \\
\hline TW1-014 & 0.00 & 0.18 & 0.00 & 0.13 & 0.00 & 0.32 & 0.00 & 0.31 & 0.00 & 0.22 & 0.00 & 0.53 \\
\hline TW1-023 & 0.00 & 0.00 & 0.01 & 0.28 & 0.00 & 0.29 & 0.00 & 0.00 & 0.01 & 0.47 & 0.00 & 0.48 \\
\hline TW1-025 & 0.00 & 0.12 & 0.00 & 0.29 & 0.00 & 0.41 & 0.00 & 0.19 & 0.00 & 0.48 & 0.00 & 0.68 \\
\hline TW1-032 & 0.00 & 0.25 & 0.00 & 0.20 & 0.00 & 0.45 & 0.00 & 0.42 & 0.01 & 0.33 & 0.00 & 0.76 \\
\hline TW1-036 & 0.00 & 0.15 & 0.00 & 0.24 & 0.00 & 0.39 & 0.00 & 0.25 & 0.00 & 0.40 & 0.00 & 0.65 \\
\hline TW1-037 & 0.00 & 0.61 & 0.01 & 0.18 & 0.00 & 0.81 & 0.00 & 1.01 & 0.02 & 0.31 & 0.00 & 1.34 \\
\hline TW1-038 & 0.00 & 0.29 & 0.00 & 0.21 & 0.00 & 0.50 & 0.00 & 0.48 & 0.00 & 0.35 & 0.00 & 0.84 \\
\hline TW1-039 & 0.00 & 0.09 & 0.00 & 0.30 & 0.00 & 0.40 & 0.00 & 0.15 & 0.01 & 0.51 & 0.00 & 0.67 \\
\hline TW1-041 & 0.00 & 1.08 & 0.01 & 0.21 & 0.00 & 1.30 & 0.00 & 1.80 & 0.02 & 0.35 & 0.00 & 2.16 \\
\hline TW1-043 & 0.00 & 0.33 & 0.00 & 0.32 & 0.00 & 0.66 & 0.00 & 0.55 & 0.00 & 0.54 & 0.00 & 1.09 \\
\hline TW1-046 & 0.00 & 0.07 & 0.00 & 0.19 & 0.00 & 0.26 & 0.00 & 0.12 & 0.00 & 0.32 & 0.00 & 0.44 \\
\hline TW1-047 & 0.00 & 2.15 & 0.01 & 0.24 & 0.00 & 2.39 & 0.00 & 3.58 & 0.01 & 0.40 & 0.00 & 3.99 \\
\hline TW1-048 & 0.00 & 0.00 & 0.00 & 0.33 & 0.00 & 0.33 & 0.00 & 0.00 & 0.00 & 0.55 & 0.00 & 0.55 \\
\hline TW1-049 & 0.00 & 1.16 & 0.00 & 0.25 & 0.00 & 1.42 & 0.00 & 1.94 & 0.01 & 0.42 & 0.00 & 2.36 \\
\hline TW1-050 & 0.00 & 0.12 & 0.00 & 0.28 & 0.00 & 0.40 & 0.00 & 0.21 & 0.00 & 0.46 & 0.00 & 0.67 \\
\hline TW1-051 & 0.00 & 0.00 & 0.00 & 0.30 & 0.00 & 0.30 & 0.00 & 0.00 & 0.00 & 0.51 & 0.00 & 0.51 \\
\hline TW1-052 & 0.01 & 3.12 & 0.12 & 0.21 & 0.00 & 3.46 & 0.01 & 5.20 & 0.20 & 0.35 & 0.00 & 5.76 \\
\hline TW1-053 & 0.00 & 0.75 & 0.00 & 0.25 & 0.00 & 1.01 & 0.00 & 1.25 & 0.01 & 0.42 & 0.00 & 1.68 \\
\hline TW1-054 & 0.00 & 1.12 & 0.00 & 0.17 & 0.00 & 1.30 & 0.00 & 1.87 & 0.00 & 0.29 & 0.00 & 2.16 \\
\hline TW1-055 & 0.00 & 0.36 & 0.00 & 0.20 & 0.00 & 0.55 & 0.00 & 0.59 & 0.00 & 0.33 & 0.00 & 0.92 \\
\hline TW1-058 & 0.00 & 0.25 & 0.00 & 0.12 & 0.00 & 0.37 & 0.00 & 0.41 & 0.01 & 0.20 & 0.00 & 0.61 \\
\hline TW1-059 & 0.00 & 0.51 & 0.00 & 0.18 & 0.00 & 0.69 & 0.00 & 0.85 & 0.00 & 0.31 & 0.00 & 1.16 \\
\hline TW1-060 & 0.00 & 1.32 & 0.01 & 0.19 & 0.00 & 1.52 & 0.00 & 2.21 & 0.01 & 0.32 & 0.00 & 2.54 \\
\hline TW1-061 & 0.00 & 0.38 & 0.00 & 0.24 & 0.00 & 0.63 & 0.00 & 0.63 & 0.00 & 0.41 & 0.00 & 1.05 \\
\hline TW2-014 & 0.00 & 0.78 & 0.00 & 0.91 & 0.27 & 1.96 & 0.00 & 1.30 & 0.00 & 1.52 & 1.04 & 3.86 \\
\hline TW2-018 & 0.00 & 0.28 & 0.10 & 1.54 & 0.23 & 2.16 & 0.00 & 0.47 & 0.17 & 2.58 & 0.90 & 4.11 \\
\hline TW2-021 & 0.00 & 4.32 & 0.06 & 0.32 & 0.00 & 4.71 & 0.00 & 7.21 & 0.11 & 0.54 & 0.00 & 7.85 \\
\hline TW2-022 & 0.00 & 0.98 & 0.00 & 0.24 & 0.00 & 1.23 & 0.00 & 1.64 & 0.00 & 0.41 & 0.00 & 2.05 \\
\hline TW2-037 & 0.00 & 0.20 & 0.01 & 0.44 & 0.00 & 0.64 & 0.00 & 0.33 & 0.01 & 0.73 & 0.00 & 1.07 \\
\hline TW2-042 & 0.01 & 0.40 & 0.05 & 0.36 & 0.00 & 0.83 & 0.01 & 0.67 & 0.09 & 0.61 & 0.00 & 1.37 \\
\hline TW2-043 & 0.00 & 0.08 & 0.00 & 0.29 & 0.00 & 0.37 & 0.00 & 0.14 & 0.00 & 0.48 & 0.00 & 0.62 \\
\hline TW2-044 & 0.00 & 0.43 & 0.10 & 0.28 & 0.02 & 0.83 & 0.00 & 0.71 & 0.17 & 0.46 & 0.09 & 1.43 \\
\hline TW2-045 & 0.00 & 0.69 & 0.08 & 0.49 & 0.00 & 1.26 & 0.00 & 1.15 & 0.13 & 0.81 & 0.00 & 2.10 \\
\hline TW2-057 & 0.00 & 0.34 & 0.02 & 0.39 & 0.00 & 0.75 & 0.00 & 0.57 & 0.04 & 0.65 & 0.00 & 1.26 \\
\hline TW2-058 & 0.00 & 0.19 & 0.00 & 0.36 & 0.02 & 0.57 & 0.00 & 0.32 & 0.00 & 0.59 & 0.09 & 1.01 \\
\hline TW2-066 & 0.00 & 1.13 & 0.01 & 0.32 & 0.00 & 1.45 & 0.00 & 1.88 & 0.01 & 0.53 & 0.00 & 2.42 \\
\hline TW2-067 & 0.00 & 0.62 & 0.06 & 0.32 & 0.25 & 1.25 & 0.00 & 1.03 & 0.10 & 0.54 & 0.97 & 2.64 \\
\hline TW2-069 & 0.00 & 0.00 & 0.00 & 0.29 & 0.00 & 0.29 & 0.00 & 0.00 & 0.00 & 0.48 & 0.00 & 0.48 \\
\hline Min & 0.00 & 0.00 & 0.00 & 0.12 & 0.00 & 0.21 & 0.00 & 0.00 & 0.00 & 0.20 & 0.00 & 0.35 \\
\hline Max & 0.01 & 4.32 & 0.12 & 1.54 & 0.27 & 4.71 & 0.01 & 7.21 & 0.20 & 2.58 & 1.04 & 7.85 \\
\hline Mean & 0.00 & 0.54 & 0.02 & 0.31 & 0.02 & 0.89 & 0.00 & 0.90 & 0.03 & 0.52 & 0.07 & 1.52 \\
\hline
\end{tabular}

In this study, $\mathrm{Cr}^{6+}$ was also considered as a carcinogenic risk pollutant. Considering the acceptable $C R_{\text {total }}$ limit set as $1 \times 10^{-6}$ by the Ministry of Environmental Protection of the P.R. China [30], the results shown in Table 7 revealed a critical carcinogenic risk by drinking and daily contact of water from six $(12.5 \%)$ wells in the study area. 


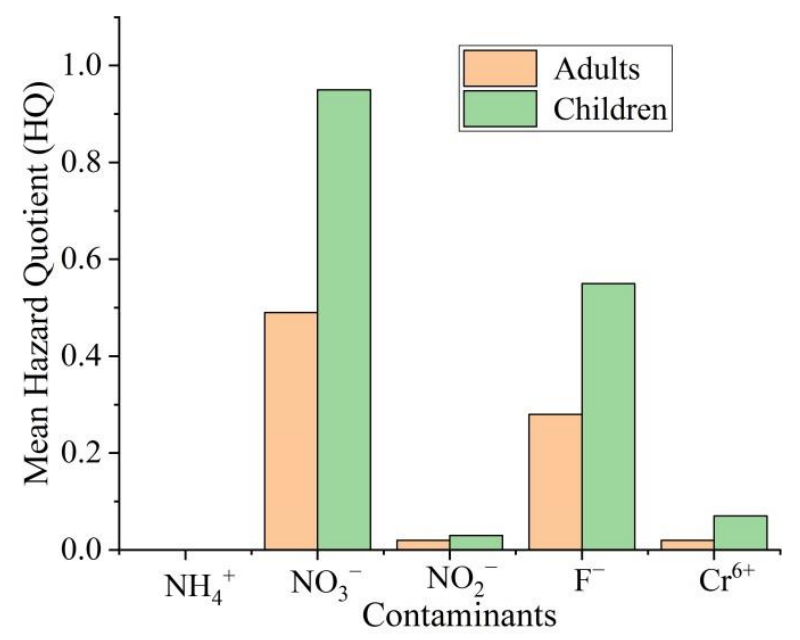

Figure 6. Representation of the mean $\mathrm{HQ}$ for non-carcinogenic $\left(\mathrm{NH}_{4}{ }^{+}, \mathrm{NO}_{3}{ }^{-}, \mathrm{NO}_{2}{ }^{-}, \mathrm{F}^{-}, \mathrm{Cr}^{6+}\right)$ contaminants.

Table 7. Calculated carcinogenic risk due to $\mathrm{Cr}^{6+}$ in water intake and dermal contact.

\begin{tabular}{ccccccccc}
\hline Samples & Adults & Children & Samples & Adults & Children & Samples & Adults & Children \\
\hline TW1-002 & 0 & 0 & TW1-038 & 0 & 0 & TW1-060 & 0 & 0 \\
TW1-003 & 0 & 0 & TW1-039 & 0 & 0 & TW1-061 & 0 & 0 \\
TW1-004 & $1.00 \times 10^{-4}$ & $2.00 \times 10^{-4}$ & TW1-041 & 0 & 0 & TW2-014 & $4.95 \times 10^{-4}$ & $8.16 \times 10^{-4}$ \\
TW1-005 & 0 & 0 & TW1-043 & 0 & 0 & TW2-018 & $4.25 \times 10^{-4}$ & $7.01 \times 10^{-4}$ \\
TW1-007 & 0 & 0 & TW1-046 & 0 & 0 & TW2-021 & 0 & 0 \\
TW1-008 & 0 & 0 & TW1-047 & 0 & 0 & TW2-022 & 0 & 0 \\
TW1-009 & 0 & 0 & TW1-048 & 0 & 0 & TW2-037 & 0 & 0 \\
TW1-010 & 0 & 0 & TW1-049 & 0 & 0 & TW2-042 & 0 & 0 \\
TW1-012 & 0 & 0 & TW1-050 & 0 & 0 & TW2-043 & 0 \\
TW1-013 & 0 & 0 & TW1-051 & 0 & 0 & TW2-044 & $4.18 \times 10^{-5}$ & $6.89 \times 10^{-5}$ \\
TW1-014 & 0 & 0 & TW1-052 & 0 & 0 & TW2-045 & 0 & 0 \\
TW1-023 & 0 & 0 & TW1-053 & 0 & 0 & TW2-057 & 0 \\
TW1-025 & 0 & 0 & TW1-054 & 0 & 0 & TW2-058 & $4.18 \times 10^{-5}$ & $6.89 \times 10^{-5}$ \\
TW1-032 & 0 & 0 & TW1-055 & 0 & 0 & TW2-066 & 0 \\
TW1-036 & 0 & 0 & TW1-058 & 0 & 0 & TW2-067 & $4.60 \times 10^{-4}$ & $7.58 \times 10^{-4}$ \\
TW1-037 & 0 & 0 & TW1-059 & 0 & 0 & TW2-069 & 0 & 0 \\
\hline
\end{tabular}

$C R_{\text {total }}$ ranges from $4.18 \times 10^{-5}$ to $4 \times 10^{-4}$ for adults and from $6.89 \times 10^{-5}$ to $8 \times 10^{-4}$ for children. Similar results have also been found by He and Wu [74], Li et al. [75], Wu and Sun [38], Liu et al. [76], Ji et al. [77], and He et al. [78] in their study on groundwater quality and health risk assessment, which confirmed the health threats faced by the population, especially for children in the loess area of northwest China. According to WHO [42], the excessive $\mathrm{Cr}^{6+}$ concentration in drinking water can cause lung cancer via inhalation route. Groundwater from wells represented by samples TW1-004, TW2-014, TW2-018, TW2-044, TW2-058, and TW2-067 with $C R_{\text {total }}$ values of more than $1 \times 10^{-6}$ must be used with precaution for drinking purposes.

\section{Conclusions}

In the present study, water quality index (WQI), statistical analysis and graphical approaches were implemented to understand the status of groundwater quality in the Tongchuan area on the Loess Plateau, northwest China. In addition, GIS approaches helped to map the WQI results of this study. Daily average exposure dosage through oral pathway was taken into consideration to calculate health risks to the human body through drinking 
water intake. For dermal contact, the exposure dosage of every single event in $\mathrm{mg} / \mathrm{cm}^{2}$ and the skin surface $\left(\mathrm{cm}^{2}\right)$ were considered. The following conclusions can be achieved:

- In summary, the results of this study demonstrated that groundwater in the study area is suitable for drinking in general. WQI approach showed that $77.1 \%$ of the samples are of excellent quality, nine samples $(18.7 \%)$ are of good quality, and two samples $(4.2 \%)$ are of poor quality.

- $\mathrm{NO}_{3}{ }^{-}, \mathrm{F}^{-}$, and $\mathrm{Cr}^{6+}$ are the most significant parameters affecting water quality in this study; $27.1 \%$ and $54.2 \%$ of the overall samples present a non-carcinogenic health risk through drinking water intake for adults and children, respectively. The $C R_{\text {total }}$ of $12.5 \%$ of the samples ranges from $4.18 \times 10^{-5}$ to $4 \times 10^{-4}$ for adults and from $6.89 \times 10^{-5}$ to $8 \times 10^{-4}$ for children, which exceeded the acceptable limit $\left(1 \times 10^{-6}\right)$.

- $\mathrm{NO}_{3}{ }^{-}$considerably contributes to non-carcinogenic risk for both adults and children and is followed by $\mathrm{F}^{-}, \mathrm{Cr}^{6+}$ and lastly by $\mathrm{NO}_{2}{ }^{-}$, with respective mean $\mathrm{HQ}$ of 0.49 , $0.28,0.02$ and 0.02 for adults. For children, the mean $\mathrm{HQ}$ for $\mathrm{NO}_{3}{ }^{-}, \mathrm{NO}_{2}{ }^{-}, \mathrm{F}^{-}$and $\mathrm{Cr}^{6+}$ are $0.95,0.03,0.55$ and 0.07 , respectively. $\mathrm{HN}_{4}{ }^{+}$has zero contribution to health risk in this study area for both adults and children. The high concentration of $\mathrm{NO}_{3}{ }^{-}$ in the study area is due to anthropogenic activities, especially fertilizers in agriculture as also discussed by previous researchers.

- WQI is not enough to conclude whether water is suitable or not for drinking. The assessment of carcinogenic and non-carcinogenic risk on the human body showed that groundwater in Tongchuan was not totally safe. Therefore, water pretreatment before drinking and taking effective measures to prevent groundwater pollution are imperative.

This study will be helpful to local decision makers for implementing measures, policy and strategies to protect groundwater resources and reduce the health risks of residents by groundwater consumption through oral and dermal pathways. It is also useful for international scholars who may find information for similar studies or its improvement.

Author Contributions: Research conceptualization, A.N. and P.L.; data curation, S.H., X.H., and A.N.; methodology, A.N.; writing—original draft, A.N.; writing—review and editing, P.L., S.H., X.H., S.M.K.A., and M.F., supervision, P.L. All authors have read and agreed to the published version of the manuscript.

Funding: This work was supported by the National Natural Science Foundation of China (42072286 and 41761144059), the Fundamental Research Funds for the Central Universities of CHD (300102299301 and 300102291507), the Fok Ying Tong Education Foundation (161098), and the Ten Thousand Talents Program (W03070125).

Institutional Review Board Statement: Not applicable.

Informed Consent Statement: Not applicable.

Data Availability Statement: All processed data generated or used during the study appear in the submitted article. Raw data may be provided on reasonable request from the corresponding author.

Acknowledgments: We acknowledge the members of the Key Laboratory of Subsurface Hydrology and Ecological Effects in Arid Region of the Ministry of Education, Chang'an University, Shaanxi, China for the groundwater samples processing. The useful and constructive comments from the editors and reviewers are sincerely acknowledged.

Conflicts of Interest: The authors declare no conflict of interest.

\section{References}

1. Li, P.; Meng, X.; Li, M.; Zhang, Y. Appraising groundwater quality and health risks from contamination in a semiarid region of Northwest China. Expo. Health 2016, 8, 361-379. [CrossRef]

2. Li, W.; Wu, J.; Zhou, C.; Nsabimana, A. Groundwater pollution source identification and apportionment using PMF and PCA-APCS-MLR receptor models in Tongchuan City, China. Arch. Environ. Contam. Toxicol. 2021, 81, 397-413. [CrossRef] [PubMed] 
3. Wei, M.; Wu, J.; Li, W.; Zhang, Q.; Su, F.; Wang, Y. Groundwater geochemistry and its impacts on groundwater arsenic enrichment, variation, and health risks in Yongning County, Yinchuan Plain of northwest China. Expo. Health 2021. [CrossRef]

4. Liu, J.; Gao, M.; Jin, D.; Wang, T.; Yang, J. Assessment of groundwater quality and human health risk in the aeolian-sand area of Yulin City, Northwest China. Expo. Health 2020, 12, 671-680. [CrossRef]

5. Wang, D.; Wu, J.; Wang, Y.; Ji, Y. Finding high-quality groundwater resources to reduce the hydatidosis incidence in the Shiqu county of Sichuan province, China: Analysis, assessment, and management. Expo. Health 2020, 12, 307-322. [CrossRef]

6. Zhang, Q.; Li, P.; Lyu, Q.; Ren, X.; He, S. Groundwater contamination risk assessment using a modified DRATICL model and pollution loading: A case study in the Guanzhong Basin of China. Chemosphere 2021. [CrossRef]

7. Mfonka, Z.N.; Ngoupayou, J.R.N.; Kpoumie, A.; Ndjigui, P.D.; Zammouri, M.; Ngouh, A.N.; Mouncherou, O.F.; Mfochive, O.F.; Rakotondrabe, F. Hydrodynamic and groundwater vulnerability assessment of the shallow aquifer of the Foumban locality (Bamoun plateau, Western-Cameroon). Arab J. Geosci. 2019, 12, 165. [CrossRef]

8. Luque-Espinar, J.A.; Chica-Olmo, M. Impacts of anthropogenic activities on groundwater quality in a detritic aquifer in SE Spain. Expo. Health 2020, 12, 681-698. [CrossRef]

9. Mthembu, P.P.; Elumalai, V.; Brindha, K.; Li, P. Hydrogeochemical processes and trace metal contamination in groundwater: Impact on human health in the Maputaland coastal aquifer, South Africa. Expo. Health 2020, 12, 403-426. [CrossRef]

10. Wang, L.; Li, P.; Duan, R.; He, X. Occurrence, controlling factors and health risks of $\mathrm{Cr}^{6+}$ in groundwater in the Guanzhong Basin of China. Expo. Health 2021. [CrossRef]

11. Li, Y.; Li, P.; Cui, X.; He, S. Groundwater quality, health risk and major influencing factors in the lower Beiluo River watershed of northwest China. Hum. Ecol. Risk Assess. 2021, 27, 1987-2013. [CrossRef]

12. Li, Y.; Li, P.; Liu, L. Source identification and potential ecological risk assessment of heavy metals in the topsoil of the Weining Plain (northwest China). Expo. Health 2021. [CrossRef]

13. Moya, C.E.R.; Raiber, M.; Taulis, M.; Cox, M.E. Hydrochemical evolution and groundwater flow processes in the Galilee and Eromanga basins, Great Artesian Basin, Australia: A multivariate statistical approach. Sci. Total Environ. 2015, 508, 411-426. [CrossRef]

14. World Health Organization (W.H.O). Guidelines for Drinking Water Quality, 4th ed.; WHO: Geneva, Switzerland, 2011.

15. Li, P.; He, S.; Yang, N.; Xiang, G. Groundwater quality assessment for domestic and agricultural purposes in Yan'an City, northwest China: Implications to sustainable groundwater quality management on the Loess Plateau. Environ. Earth Sci. 2018, 77, 775. [CrossRef]

16. Singh, S.; Janaedhana, R.N.J.; Ramakrishna, C. Evaluation of groundwater quality and its suitability for domestic and irrigation use in parts of the Chandauli-Varanasi region, Uttar Pradesh, India. J. Water Res. Prot. 2015, 7, 572-582. [CrossRef]

17. Abiriga, D.; Vestgarden, L.; Klempe, H. Groundwater contamination from a municipal landfill: Effect of age, landfill closure, and season on groundwater chemistry. Sci. Total Environ. 2020, 737, 140307. [CrossRef]

18. Beyene, G.; Fufa, F.; Aberra, D. Evaluation of the suitability of groundwater for drinking and irrigation purposes in Jimma Zone of Oromia, Ethiopia. Groundw. Sustain. Dev. 2019, 9, 100216. [CrossRef]

19. Ketchemen-Tandia, B.; Boum-Nkot, S.; Ebondji, S.; Nlend, B.; Emvoutou, H.; Nzegue, O. Factors Influencing the shallow groundwater quality in four districts with different characteristics in urban area (Douala, Cameroon). J. Geosci. Environ. Prot. 2017, 5, 99-120. [CrossRef]

20. Smahi, D.; Hammoumi, O.; Fekri, A. Assessment of the impact of the landfill on groundwater quality: A case study of the Mediouna site, Casablanca, Morocco. J. Water Res. Prot. 2013, 5, 440-445. [CrossRef]

21. Li, P.; Tian, R.; Liu, R. Solute geochemistry and multivariate analysis of water quality in the Guohua Phosphorite Mine, Guizhou Province, China. Expo. Health 2019, 11, 81-94. [CrossRef]

22. Tiwari, A.K.; Orioli, S.; De Maio, M. Assessment of groundwater geochemistry and diffusion of hexavalent chromium contamination in an industrial town of Italy. J. Contam. Hydrol. 2019, 225, 103503. [CrossRef] [PubMed]

23. $\mathrm{Wu}, \mathrm{J} . ; \mathrm{Li}, \mathrm{P}$; Qian, H. Environmental chemistry of groundwater near an industrial area, Northwest China. Asian J. Chem. 2013, 25, 9795-9799. [CrossRef]

24. Zacchaeus, O.O.; Adeyemi, M.B.; Adedeji, A.A.; Adegoke, K.A.; Anumah, A.O.; Taiwo, A.M.; Ganiyu, S.A. Effects of industrialization on groundwater quality in Shagamu and Ota industrial areas of Ogun state, Nigeria. Heliyon 2020, 6, e04353. [CrossRef] [PubMed]

25. Papazotos, P.; Vasileiou, E.; Perraki, M. The synergistic role of agricultural activities in groundwater quality in ultramafic environments: The case of the Psachna basin, central Euboea, Greece. Environ. Monit. Assess. 2019, 191, 317. [CrossRef]

26. Vasileiou, E.; Papazotos, P.; Dimitrakopoulos, D.; Perraki, M. Hydrogeochemical processes and natural background levels of chromium in an ultramafic environment. The case study of Vermio mountain, Western Macedonia, Greece. Water 2021, 13, 2809. [CrossRef]

27. Chen, J.; Qian, H.; Wu, H.; Gao, Y.; Li, X. Assessment of arsenic and fluoride pollution in groundwater in Dawukou area, Northwest China, and the associated health risk for inhabitants. Environ. Earth Sci. 2017, 73, 314. [CrossRef]

28. Zissimos, A.M.; Christoforou, I.C.; Christofi, C.; Rigas, M.; Georgiadou, E.C.; Christou, A. Occurrence and distribution of hexavalent chromium in ground and surface waters in Cyprus. Bull. Environ. Contam. Toxicol. 2021, 106, 428-434. [CrossRef] 
29. Papazotos, P.; Vasileiou, E.; Perraki, M. Elevated groundwater concentrations of arsenic and chromium in ultramafic environments controlled by seawater intrusion, the nitrogen cycle, and anthropogenic activities: The case of the Gerania Mountains, NE Peloponnese, Greece. Appl. Geochem. 2020, 121, 104697. [CrossRef]

30. Ministry of Environmental Protection of the P.R. China. Technical Guidelines for Risk Assessment of Contaminated Sites, HJ 25.3-2014; China Environmental Science Press: Beijing, China, 2014.

31. Adimalla, N.; Vasa, S.K.; Li, P. Evaluation of groundwater quality, Peddavagu in Central Telangana (PCT), South India: An insight of controlling factors of fluoride enrichment. Modeling Earth Syst. Environ. 2018, 4, 841-852. [CrossRef]

32. Choi, B.Y.; Yun, S.T.; Yu, S.Y.; Lee, P.K.; Park, S.S.; Chae, G.T. Hydrochemistry of urban groundwater in Seoul, South Korea: Effect of land use and pollutant recharge. Environ. Geol. 2005, 48, 979-990. [CrossRef]

33. Johnson, R. Drinking water quality: Testing and interpreting your results. In NDSU; USDA-NIFA: North Dakota State University: Fargo, ND, USA, 2019.

34. Wei, Y.; Fan, W.; Wang, W.; Deng, L. Identification of nitrate pollution sources of groundwater and analysis of potential pollution paths in loess regions: A case study in Tongchuan region, China. Environ. Earth Sci. 2017, 76, 423. [CrossRef]

35. Wang, Y.; Li, P. Appraisal of shallow groundwater quality with human health risk assessment in different seasons in rural areas of the Guanzhong Plain (China). Environ. Res. 2021. [CrossRef]

36. Wu, C.; Fang, C.; Wu, X.; Zhu, G. Health-risk assessment of arsenic and groundwater quality classification using random forest in the Yanchi Region of Northwest China. Expo. Health 2020, 12, 761-774. [CrossRef]

37. Ni, F.; Liu, G.; Ye, J.; Ren, H.; Yang, S. ArcGIS-based rural drinking water quality health risk assessment. J. Water Res. Prot. 2009, 1, 351-361. [CrossRef]

38. $\mathrm{Wu}, \mathrm{J} . ;$ Sun, Z. Evaluation of shallow groundwater contamination and associated human health risk in an alluvial plain impacted by agricultural and industrial activities, mid-west China. Expo. Health 2016, 8, 311-329. [CrossRef]

39. Li, X.; Wu, H.; Qian, H.; Gao, Y. Groundwater chemistry regulated by hydrochemical processes and geological structures: A case study in Tongchuan, China. Water 2018, 10, 338. [CrossRef]

40. Xiao, J.; Jin, Z.D.; Zhang, F. Geochemical controls on fluoride concentrations in natural waters from the middle Loess Plateau, China. J. Geochem. Explor. 2015, 159, 252-261. [CrossRef]

41. World Health Organization (W.H.O). Guidelines for Drinking Water Quality, 3rd ed.; Incorporating the First and Second Addendum; WHO: Geneva, Switzerland, 2008.

42. World Health Organization (W.H.O). Guidelines for Drinking-Water Quality, 4th ed.; Incorporating the First Addendum; WHO: Geneva, Switzerland, 2017.

43. General Administration of Quality Supervision, Inspection and Quarantine of China, Standardization Administration of China. Standards for Groundwater Quality (GB/T 14848-2017.); General Administration of Quality Supervision: Beijing, China, 2017.

44. Vasileiou, E.; Papazotos, P.; Dimitrakopoulos, D.; Perraki, M. Expounding the origin of chromium in groundwater of the Sarigkiol basin, Western Macedonia, Greece: A cohesive statistical approach and hydrochemical study. Environ. Monit. Assess. 2019, 191, 509. [CrossRef]

45. Piper, A.M. A graphic procedure in the geochemical interpretation of water analysis. Trans. Am. Geophys. Union 1954, 25, 914-928. [CrossRef]

46. Durov, S.A. Natural waters and graphic representation of their composition. Dokl. Akad. Nauk. SSSR 1948, 59, 87-90.

47. Boufekane, A.; Saighi, O. Assessing groundwater quality for irrigation using geostatistical method-Case of Wadi Nil Plain (North-East Algeria). Groundw. Sustain. Dev. 2019, 8, 179-186. [CrossRef]

48. Bordalo, A.A.; Teixeira, R.; Wiebe, W.J. A water quality index applied to an international shared river basin: The case of the Douro River. Environ. Manag. 2006, 38, 910-920. [CrossRef] [PubMed]

49. Li, P.; Qian, H.; Wu, J. Groundwater quality assessment based on improved water quality index in Pengyang County, Ningxia, Northwest China. E-J. Chem. 2010, 7, S209-S216. [CrossRef]

50. Şener, Ş.; Şener, E.; Davraz, A. Assessment of groundwater quality and health risk in drinking water basin using GIS. J. Water Health 2016, 15, 112-132. [CrossRef] [PubMed]

51. Varol, S.; Davraz, A. Evaluation of potential human health risk and investigation of drinking water quality in Isparta city center (Turkey). J. Water Health 2015, 14, 471-488. [CrossRef] [PubMed]

52. Singh, S.; Janardhana, R.N.J.; Ramakrishna, C. Assessment and monitoring of groundwater quality in semi-arid region. Groundw. Sustain. Dev. 2020, 11, 100381. [CrossRef]

53. Tirkey, P.; Bhattacharya, T.; Chakraborty, S. Water quality indices- important tools for water quality assessment: A review. Int. J. Adv. Chem. 2013, 1, 15-28. [CrossRef]

54. Hamed, S.; Omid, N.; Mahbobehv, G.; Abooalfazl, A.; Mansooreh, D.; Majid, R.; Mohammad, D.; Vahide, O.; Maryam, H. Groundwater quality evaluation and risk assessment of nitrate using monte carlo simulation and sensitivity analysis in rural areas of Divandarreh County, Kurdistan province, Iran. Int. J. Environ. Anal. Chem. 2020. [CrossRef]

55. U.S.E.P.A. Supplemental Environmental Projects (SEP) Policy 2015 Update. EPA. 2015: Washington. Available online: https: //www.epa.gov/sites/default/files/2015-04/documents/sepupdatedpolicy15.pdf (accessed on 13 October 2020).

56. Hem, J.D. Study and Interpretation of the Chemical Characteristics of Natural Water. US Geological Survey. 3 ed, Water-Supply, 1985. Paper 2254, 263. Available online: https:/ / pubs.usgs.gov/wsp/wsp2254/html/pdf.html (accessed on 21 November 2020).

57. Mechenich, C.; Andrews, E. Evaluating the condition of your private water supply. Interpreting 1993, 3558, 1-8. 
58. Freeze, R.A.; Cherry, J.A. Grounndwater; Prentice-Hall: Englewood Cliffs, NJ, USA, 1979; p. 604.

59. Davis, S.N.; De Wiest, R.J.M. Hydrogeology; John Wiley and Sons: Hoboken, NJ, USA, 1966; Volume 463, p. 824.

60. Adimalla, N. Occurrence, health risks, and geochemical mechanisms of fluoride and nitrate in groundwater of the rock-dominant semi-arid region, Telangana State, India. Hum. Ecol. Risk Assess. 2018, 25, 81-103. [CrossRef]

61. Mohan, D.S.R.; Singh, V.K.; Steele, P.; Pittman, C.U. Fluoride removal from water using bio-char, a green waste, low-cost adsorbent: Equilibrium uptake and sorption dynamics modeling. Ind. Eng. Chem. Res. 2012, 51, 900-914. [CrossRef]

62. Emenike, C.P.; Tenebe, I.T.; Jarvis, P. Fluoride contamination in groundwater sources in Southwestern Nigeria: Assessment using multivariate statistical approach and human health risk. Ecotoxicol. Environ. Saf. 2018, 156, 391-402. [CrossRef]

63. Kaoud, H.; Kalifa, B. Effect of fluoride, cadmium and arsenic intoxication on brain and learning-memory ability in rats. Toxicol. Lett. 2010, 196, S53. [CrossRef]

64. Kimambo, V.; Bhattacharya, P.; Mtalo, F.; Mtamba, J.; Ahmad, A. Fluoride occurrence in groundwater systems at global scale and status of defluoridation-State of the art. Groundw. Sustain. Dev. 2019, 9, 100223. [CrossRef]

65. Sivasankar, V.; Darchen, A.; Omine, K.; Sakthivel, R. Fluoride: A world ubiquitous compound, its chemistry, and ways of contamination. In Surface Modified Carbons as Scavengers for Fluoride from Water; Sivasankar, V., Ed.; Springer: Cham, Switzerland, 2016; pp. 5-32. [CrossRef]

66. Vithanage, M.; Bhattacharya, P. Fluoride in drinking water: Health effects and remediation. In $\mathrm{CO}_{2}$ Sequestration Biofuels and Depollution; Lichtfouse, E., Schwarzbauer, J., Robert, D., Eds.; Springer: Cham, Switzerland, 2015; pp. 105-151. [CrossRef]

67. Saxena, V.; Ahmed, S. Inferring the chemical parameters for the dissolution of fluoride in groundwater. Environ. Geol. 2003, 43, 731-736. [CrossRef]

68. Rango, T.; Kravchenko, J.; Atlaw, B.; McCornick, P.G.; Jeuland, M.; Merola, B.; Vengosh, A. Groundwater quality and its health impact: An assessment of dental fluorosis in rural inhabitants of the Main Ethiopian Rift. Environ. Int. 2012, 43, 37-47. [CrossRef]

69. Marghade, D.; Malpe, D.B.; Zade, A.B. Major ion chemistry of shallow groundwater of a fast growing city of Central India. Environ. Monit. Assess. 2012, 184, 2405-2418. [CrossRef]

70. Ravikumar, P.; Somashekar, R.K.; Prakash, K.L. A comparative study on usage of Durov and Piper diagrams to interpret hydrochemical processes in groundwater from SRLIS river basin, Karnataka, India. Elixir Earth Sci. 2015, 80, 31073-31077.

71. Lloyd, J.A.; Heathcote, J.A. Natural Inorganic Hydrochemistry in Relation to Groundwater: An Introduction; O.U. Press: New York, NY, USA, 1985; p. 296.

72. Xu, P.; Feng, W.; Qian, H.; Zhang, Q. Hydrogeochemical characterization and irrigation quality assessment of shallow groundwater in the Central-Western Guanzhong Basin, China. Int. J. Environ. Res. Public Health 2019, 16, 1492. [CrossRef]

73. Singh, S.; Janardhana, R.N.J.; Ramakrishna, C. Hydrogeochemical assessment of surface and groundwater resources of Korba coalfield, Central India: Environmental implications. Arab J. Geosci. 2017, 10, 318. [CrossRef]

74. He, S.; Wu, J. Hydrogeochemical characteristics, groundwater quality, and health risks from hexavalent chromium and nitrate in groundwater of Huanhe formation in Wuqi County, Northwest China. Expo. Health 2019, 11, 125-137. [CrossRef]

75. Li, P.; He, X.; Guo, W. Spatial groundwater quality and potential health risks due to nitrate ingestion through drinking water: A case study in Yan'an City on the Loess Plateau of northwest China. Hum. Ecol. Risk Assess. 2019, 25, 11-31. [CrossRef]

76. Liu, L.; Wu, J.; He, S.; Wang, L. Occurrence and distribution of groundwater fluoride and manganese in the Weining Plain (China) and their probabilistic health risk quantification. Expo. Health 2021. [CrossRef]

77. Ji, Y.; Wu, J.; Wang, Y.; Elumalai, V.; Subramani, T. Seasonal variation of drinking water quality and human health risk assessment in Hancheng City of Guanzhong Plain, China. Expo. Health 2020, 12, 469-485. [CrossRef]

78. He, X.; Wu, J.; He, S. Hydrochemical characteristics and quality evaluation of groundwater in terms of health risks in Luohe aquifer in Wuqi County of the Chinese Loess Plateau, northwest China. Hum. Ecol. Risk Assess. 2019, 25, 32-51. [CrossRef] 